\title{
A Statistical-Mathematical Model to Optimize Chicken Feather Waste Bioconversion via Bacillus licheniformis SHG10: A Low Cost Effective and Ecologically Safe Approach
}

Amira M Embaby ${ }^{1 *}$, Heba S Marey ${ }^{2,3}$ and Ahmed Hussein ${ }^{1}$

${ }^{1}$ Institute of Graduate Studies and Research, Department of Biotechnology, University of Alexandria, Egypt

${ }^{2}$ Institute of Graduate Studies and Research, Department of Environmental Studies, University of Alexandria, Egypt

${ }^{3}$ University of Alberta, Department of Civil and Environmental Engineering, Edmonton, AB, Canada

\begin{abstract}
Feather waste is highly accumulated recalcitrant and non-efficiently utilized protein wastage of poultry processing Present study highlights a cheap eco-friendly approach towards its valorization into efficiently utilized form (feather hydrolysate (SHG10 FH)) through Bacillus licheniformis SHG10 within $48 \mathrm{hrs}$. A statistical-mathematical model (Plackett-Burman Design (PBD), Central Composite Design (CCD), Canonical Analysis (CA) and Steepest Rising Ridge (SRR)) was anticipated to optimize feather bioconversion. PBD addressed three key determinants out of eight tested factors imposing significant influence $(P \leq 0.006)$ on soluble proteins productivity. Optimal levels of the key determinants, localized by CCD, CA and SRR, were $1.55 \%(\mathrm{w} / \mathrm{v})$ feather, $0.45 \%(\mathrm{w} / \mathrm{v})$ yeast extract and $10.8 \%(\mathrm{v} / \mathrm{v})$ inoculum size in basal medium II to attain $402 \mathrm{mg} /$ Liter soluble proteins and 104,000 $\mu$ mole leucine/Liter $\mathrm{NH}_{2}$-free amino groups. SHG10 FH was rich in phenylalanine, tyrosine, methionine and histidine. MALDI-TOF-MS showed proteins spectrum of SHG10 FH ranged from $140 \mathrm{Da} \mathrm{m} / \mathrm{z}$. to $733 \mathrm{Da} \mathrm{m} / \mathrm{z}$. The composition of SHG10 FH along with the ecologically safe low cost effective approach involved in its preparation might underpin its great potential in several industries (e.g., amino acids, soluble proteins, cosmetics and animal feed livestock).
\end{abstract}

Keywords: Ecologically safe low-cost effective approach; Bacillus licheniformis SHG10; Chicken feather waste bioconversion; Statisticalmathematical model

\section{Introduction}

Worldwide poultry processing plants generate billions of tons of chicken feathers waste, annually [1-4]. This waste is highly rich $(>90 \%)$ in recalcitrant protein namely called keratin that might make this waste a potential alternative to highly expensive dietary animal feedstuffs $[5,6]$. However, its recalcitrant nature imposes resistance to degradation by common proteolytic enzymes. This in turn makes feather waste non-efficiently utilized in its native form on a dietary basis. Resistance to degradation by proteolytic enzymes is mainly attributed to its complicated structural configuration imposed by tightly packed keratin polypeptides chains, high cross linking, disulphide bridges, salt linkages and hydrogen bonds [5,7-9]. Currently methods employed for disposal of this waste (e.g., dumping, usage in landfill and incineration or burring) would result in troublesome environmental problems in handling, storage, emission control and ash disposal [10-12]. In addition, discarded feathers in the environment cause some human ailments such as chlorosis and mycoplasmosis [13]. From another side, its traditional conversion thermally or chemically into feather meal results in formation of an end product of low nutritional value due to loss of some essential amino acids (e.g., methionine, lysine and histidine) as a consequence of exposure to such harsh conditions. This in turn delimits the usage of either stem cooked or alkali treated feather meal on a dietary basis. Moreover, physicochemical methods involved in treatment of feather waste require intensive energy and high cost $[14,15]$. So far, chicken feather waste management is being not only non-profitable but also non-environmentally eco-friendly.

The aforementioned shortcomings addressed the urgent need for finding alternative solutions. In this respect, microbial feather biodegradation is considered the substantial solution to overcome all the drawbacks encountered in traditional methods for feather recycling. The up to date literature contains plethora of feather- degrading microorganisms synonymously called keratinase-producing microorganisms and their keratinolytic enzymes belonging to bacteria ,actinomycetes in majority and fungi in minority [5,7,16-23]. Seeking for novel microbes with promising feather-degrading capabilities is currently the main concern of numerous researches in this respect [24-28]. It is worth mentioning that directing the process of feather degradation by powerful keratinase-producing microorganisms would help fulfill four indispensable prerequisites: a) environmentally safe bioprocess, b) economically low cost effective bioprocess, c) high nutritionally retained end products and d) high potential feather hydrolysates in numerous industries.

There exists a plethora of reports in the literature focusing on statistical optimization of keratinases production from featherdegrading microorganisms [16,22,29-35]. To the best of our knowledge, the present research article is the second one considering a two-step statistical-mathematical model to optimize chicken feather waste (hard to biodegrade insoluble protein waste) bioconversion into feather hydrolysates (rich in soluble proteins and amino acids) directed by an environmentally eco-friendly wild type feather-degrading bacterium, Bacillus licheniformis SHG10.

*Corresponding author: Amira Mohamed Embaby, Institute of Graduate Studies and Research, Department of Biotechnology, University of Alexandria, 163 Horreya Avenue, Chatby 21526, P.O. Box 832, Egypt, Tel: +20-122-034-1162 E-mail: amira_mohamed_2000@yahoo.com or amirae20@gmail.com

Received June 08, 2015; Accepted June 17, 2015; Published June 22, 2015

Citation: Embaby AM, Marey HS, Hussein A (2015) A Statistical-Mathematical Model to Optimize Chicken Feather Waste Bioconversion via Bacillus licheniformis SHG10: A Low Cost Effective and Ecologically Safe Approach. J Bioprocess Biotech 5: 231 doi:10.4172/2155-9821.1000231

Copyright: (c) 2015 Embaby AM, et al. This is an open-access article distributed under the terms of the Creative Commons Attribution License, which permits unrestricted use, distribution, and reproduction in any medium, provided the original author and source are credited. 
Citation: Embaby AM, Marey HS, Hussein A (2015) A Statistical-Mathematical Model to Optimize Chicken Feather Waste Bioconversion via Bacillus licheniformis SHG10: A Low Cost Effective and Ecologically Safe Approach. J Bioprocess Biotech 5: 231 doi:10.4172/2155-9821.1000231

Page 2 of 14

\section{Materials and Methods}

\section{Bacterial strain}

Bacillus licheniformis SHG10 Strain, Egyptian soil bacterium, was employed in this study to direct the process of chicken feather bioconversion. This bacterial strain was previously identified through biochemical and 16S rDNA molecular approach (unpublished data). Furthermore, its $16 \mathrm{~S}$ rDNA nucleotide sequence was deposited in the GenBank (under accession number: JN853580). The proteolytic activity of this bacterial strain was proved in a previous study (unpublished data). In addition, the gene encoding the alkaline protease activity from this strain was previously isolated and its nucleotide sequence was deposited in the GenBank (under accession number: JN853581).

\section{Chicken feather waste}

Chicken feather waste of white hens, collected from poultry plants in Alexandria City, was washed thoroughly with tap water then with distilled water. After that, it was allowed to air dry and was chopped roughly into pieces.

\section{Media}

Peptone Yeast extract (PY) (10 g bactopeptone, $5 \mathrm{~g}$ yeast extract, and $5 \mathrm{~g} \mathrm{NaCl}$ per liter) medium was used in this study to activate the bacterial strain [36]. PA is PY medium supplemented with $1.5 \%(\mathrm{w} / \mathrm{v})$ agar. Whilst, PA milk medium is PA supplemented with $0.5 \%(\mathrm{w} / \mathrm{v})$ skimmed milk powder. basal medium II $\left(0.5 \mathrm{~g} \mathrm{NH}_{4} \mathrm{Cl}, 0.5 \mathrm{~g} \mathrm{NaCl}, 0.3\right.$ $\mathrm{g} \mathrm{K}_{2} \mathrm{HPO}_{4}, 0.4 \mathrm{~g} \mathrm{KH}_{2} \mathrm{PO}_{4}, 0.1 \mathrm{~g} \mathrm{MgCl}_{2}$ and $0.1 \mathrm{~g}$ yeast extract per liter) supplemented with $1 \%$ chopped chicken feather waste unless otherwise stated was used during the course of bioconversion of feather waste unless otherwise stated [2]. All media had adjusted $\mathrm{pH}$ of 7.2.

\section{Seed culture preparation}

A fine touch of B. licheniformis SHG 10 preserved on PA slant was streaked on PA milk plates to check the proteolytic activity of this bacterial strain. The inoculated plates were incubated overnight at $37^{\circ} \mathrm{C}$ (JSGI-100T, Incubator, and Korea). Next day, bacterial colonies surrounded with halo of hydrolysis were picked and were transferred to $50 \mathrm{~mL}$ PY broth in $250 \mathrm{~mL}$ Erlenmeyer flask. The inoculated broth was incubated at $37^{\circ} \mathrm{C}$, at $200 \mathrm{rpm}$ (New Brunswick Incubator Shaker, USA). The culture was incubated for 4 hrs until absorbance at $420 \mathrm{~nm}$ (Shimadzu UVPC-3200 (Kyoto, Japan)) of this culture was reached to 0.88 . After that, one $\mathrm{mL}$ of this culture (seed culture) unless otherwise stated was centrifuged at $7,000 \mathrm{rpm}$ in a microcentrifuge (Hettich Mikro 200, Germany) and the bacterial pellet was used to inoculate 50 $\mathrm{mL}$ of the production medium (basal medium II supplemented with chopped chicken feather waste) in $250 \mathrm{~mL}$ Erlenmeyer flask.

\section{Determination of soluble proteins}

Soluble proteins released during the course of feather biodegradation directed by $B$. licheniformis SHG10 were estimated according to the method previously reported [37]. A standard curve using Bovine Serum Albumin (BSA) was established.

\section{Determination of $\mathrm{NH}_{2}$-free amino groups}

$\mathrm{NH}_{2}$-free amino groups derived from feather biodegradation directed by $B$. licheniformis SHG10 were assayed according to the method previously described [38]. A standard curve using the amino acid leucine was established.

\section{Determination of amino acids}

Amino acids content of SHG10 feather hydrolysates (SHG10 FH) was analyzed using Beckman 119 CL amino acid analyzer [39].

\section{Matrix-assisted laser-desorption ionization-Time of Flight- mass spectrophotometer (MALDI-TOF-MS)}

SHG10 FH was analyzed by MALDI-TOF-MS. This was performed on Voyager DE-STR (Applied Biosystems, Framingham, MA) operated in the reflector positive mode. The feather hydrolysates (1 $\mu \mathrm{L}$ ) applied to a MALDI plate along with an equal volume of matrix solution saturated solution of $\alpha$-cyanocinnamic acid in 1:1-0.1\% TFA: acetonitrile) [40].

\section{Experimental Designs}

\section{Plackett Burman Design}

Placket Burman Design (PBD), a statistical model developed by two statisticians (Plackett and Burman) [41], is a powerful tool to screen the key determinants (physicochemical parameters) involved in bioprocesses. This design was employed in this study to highlight the key determinants involved in chicken feather bioconversion directed by B. licheniformis SHG10. Eight independent variables (feather percent, peptone, yeast extract, $\mathrm{NH}_{4} \mathrm{Cl}$, incubation time, inoculum size, casamino acids and $\mathrm{K}_{2} \mathrm{HPO}_{4}$ ) were tested here. Each independent variable coded as -1 and +1 was tried in two different concentrations (low level and high level). Real values along with coded values of the eight tested independent variables were elucidated in Table 1. This design (a fractional of two level factorial designs) allows testing of $\mathrm{N}$ variables in $\mathrm{N}+1$ experiments. The frequency of each level of a variable should be equal and that in each test the number of high and low variables should be equal. Here, the applied matrix contained 12 trials (experiments) as described in Table 1. The dependent variables (process outcome) were soluble proteins and $\mathrm{NH}_{2}$-free amino groups. Biodegradation processes in the twelve experiments were conducted in $250 \mathrm{~mL}$ of Erlenmeyer flasks containing $50 \mathrm{~mL}$ production medium at $37^{\circ} \mathrm{C}$ at $150 \mathrm{rpm}$ (New Brunswick Incubator Shaker, USA). Each trial was conducted in triplicates and the average of three readings was taken. The correlation between the dependent and the independent variables was stated as a polynomial equation from the first order as follow:

$$
\mathrm{Y}=\beta 0+\beta 1 \mathrm{X} 1+\beta 2 \mathrm{X} 2+\beta 3 \mathrm{X} 3+\beta 4 \mathrm{X} 4+\beta 5 \mathrm{X} 5+\beta 6 \mathrm{X} 6+\beta 7 \mathrm{X} 7+\beta 8 \mathrm{X} 8
$$

Where $\mathrm{Y}$ is the dependent variable (soluble proteins or $\mathrm{NH}_{2}$-free amino groups), $\beta 0$ is the model intercept, $\left(\mathrm{X}_{1}-\mathrm{X}_{8}\right)$ are the level of the independent variables and $(\beta 1-\beta 8)$ are the linear coefficients for the independent variables. This model does not illustrate the interaction between the independent variables but it does only highlight the key determinants that assess significant linear consequence on the response (dependent variable). Factors (independent variables) significant at $\mathrm{P} \leq$ 0.02 were considered to have significant consequence on the response.

\section{Response surface methodology}

Central Composite Design (CCD) was employed in this study in order to determine the optimal concentration of each factor exhibiting significant impact on the responses as derived from PBD. CCD is an experimental design useful in response surface methodology for constructing a second order model for the response variable [42]. The three factors highlighted by PBD were feather percent, inoculum 
Citation: Embaby AM, Marey HS, Hussein A (2015) A Statistical-Mathematical Model to Optimize Chicken Feather Waste Bioconversion via Bacillus licheniformis SHG10: A Low Cost Effective and Ecologically Safe Approach. J Bioprocess Biotech 5: 231 doi:10.4172/2155-9821.1000231

Page 3 of 14

\begin{tabular}{|c|c|c|c|c|c|c|c|c|c|c|c|c|}
\hline \multirow{3}{*}{$\begin{array}{c}\text { Trial } \\
\#\end{array}$} & \multicolumn{8}{|c|}{ Independent variable } & \multicolumn{4}{|c|}{ Dependent variable } \\
\hline & \multirow{2}{*}{$\begin{array}{c}\text { Feather } \\
\left(X_{1}\right)\end{array}$} & \multirow{2}{*}{ Peptone $\left(\mathbf{X}_{2}\right)$} & \multirow{2}{*}{$\begin{array}{c}\text { Yeast } \\
\text { extract }\left(X_{3}\right)\end{array}$} & \multirow{2}{*}{$\begin{array}{c}\mathrm{NH}_{4} \mathrm{Cl} \\
\left(\mathrm{X}_{4}\right)\end{array}$} & \multirow{2}{*}{$\begin{array}{l}\text { Incubation time } \\
\qquad\left(X_{5}\right)\end{array}$} & \multirow{2}{*}{$\begin{array}{c}\text { Inoculum } \\
\text { Size }\left(X_{6}\right)\end{array}$} & \multirow{2}{*}{$\begin{array}{l}\text { Casamino } \\
\text { acids }\left(X_{7}\right)\end{array}$} & \multirow{2}{*}{$\mathrm{K}_{2} \mathrm{HPO}_{4}\left(\mathrm{X}_{8}\right)$} & \multicolumn{2}{|c|}{$\begin{array}{l}\text { Soluble proteins } \\
(\mathrm{mg} / \mathrm{mL})\left(\mathrm{Y}_{1}\right)\end{array}$} & \multicolumn{2}{|c|}{$\begin{array}{l}\mathrm{NH}_{2} \text {-free amino groups } \\
\left(\mu \mathrm{mole} \text { leucine/mL }\left(\mathrm{Y}_{2}\right)\right.\end{array}$} \\
\hline & & & & & & & & & Exp. $^{a}$ & Pred. ${ }^{b}$ & Exp. $^{a}$ & Pred. $^{b}$ \\
\hline 1 & $1(1.0)$ & $-1(0.0)$ & $1(0.15)$ & $-1(0.05)$ & $-1(24)$ & $-1(2)$ & $1(0.2)$ & $1(0.15)$ & 0.110 & 0.110 & 45.2 & 40.90 \\
\hline 2 & $1(1.0)$ & $1(0.1)$ & $-1(0.01)$ & $1(0.15)$ & $-1(24)$ & $-1(2)$ & $-1(0.0)$ & $1(0.15)$ & 0.020 & 0.025 & 53.3 & 59.30 \\
\hline 3 & $-1(0.3)$ & $1(0.1)$ & $1(0.15)$ & $-1(0.05$ & $1(48)$ & $-1(2)$ & $-1(0.0)$ & $-1(0.03)$ & 0.095 & 0.104 & 41.9 & 39.91 \\
\hline 4 & $1(1.0)$ & $-1(0.0)$ & $1(0.15)$ & $1(0.15)$ & $-1(24)$ & $1(6)$ & $-1(0.0)$ & $-1(0.03)$ & 0.128 & 0.132 & 82.0 & 77.54 \\
\hline 5 & $1(1.0)$ & $1(0.1)$ & $-1(0.01)$ & $1(0.15)$ & $1(48)$ & $-1(2)$ & $1(0.2)$ & $-1(0.03)$ & 0.065 & 0.060 & 64.9 & 59.67 \\
\hline 6 & $1(1.0)$ & $1(0.1)$ & $1(0.15)$ & $-1(0.05$ & $1(48)$ & $1(6)$ & $-1(0.0)$ & $1(0.15)$ & 0.245 & 0.236 & 61.8 & 64.46 \\
\hline 7 & $-1(0.3)$ & $1(0.1)$ & $1(0.15)$ & $1(0.15)$ & $-1(24)$ & $1(6)$ & $1(0.2)$ & $-1(0.03)$ & 0.094 & 0.090 & 35.4 & 39.83 \\
\hline 8 & $-1(0.3)$ & $-1(0.0)$ & $1(0.15)$ & $1(0.15)$ & $1(48)$ & $-1(2)$ & $1(0.2)$ & $1(0.15)$ & 0.032 & 0.032 & 41.7 & 45.26 \\
\hline 9 & $-1(0.3)$ & $-1(0.0)$ & $-1(0.01)$ & $1(0.15)$ & $1(48)$ & $1(6)$ & $-1(0.0)$ & $1(0.15)$ & 0.074 & 0.074 & 52.9 & 48.63 \\
\hline 10 & $1(1.0)$ & $-1(0.0)$ & $-1(0.01)$ & $-1(0.05)$ & $1(48)$ & $1(6)$ & $1(0.2)$ & $-1(0.03)$ & 0.176 & 0.181 & 40.0 & 45.32 \\
\hline 11 & $-1(0.3)$ & $1(0.1)$ & $-1(0.01)$ & $-1(0.05)$ & $-1(24)$ & $1(6)$ & $1(0.2)$ & $1(0.15)$ & 0.100 & 0.103 & 11.0 & 7.25 \\
\hline 12 & $-1(0.3)$ & $-1(0.0)$ & $-1(0.01)$ & $-1(0.05)$ & $-1(24)$ & $-1(2)$ & $-1(0.0)$ & $-1(0.03)$ & 0.021 & 0.012 & 18.4 & 20.41 \\
\hline
\end{tabular}

- Values between in brackets are real values of independent variables.

- Real values of all independent variables except time and inoculum size are taken in terms of \%W/V.

- Real values for the independent variable time are $24 \mathrm{hrs}$ and $48 \mathrm{hrs}$

- Real values for the independent variable inoculum size are taken in terms of $\% \mathrm{~V} / \mathrm{V}$ providing that one $\mathrm{mL}$ of culture contained $5.0 \times 10^{6} \mathrm{CFU} / \mathrm{mL}$.

- a: Experimental values b: Predicted values

Table 1: PBD and levels of eight independent variables in terms of coded and real values along with levels of corresponding experimental dependent variables.

size and yeast extract. Two level orthogonal full factorial central composite design with six star points and one center point replicating five times resulting in a total of twenty experiments (trials) were employed to examine the effectuation of the selected factors on the aforementioned two process outcomes. Real values along with coded values of the three tested independent variables were shown in Table 2. A second polynomial equation was fitted to define all possible forms of interactions between each response and the three selected factors from PBD in order to predict the optimal point of each factor. The polynomial equation is:

$$
Y=\beta 0+\beta 1 X 1+\beta 3 X 3+\beta 6 X 6+\beta 11 X 1 . X 1+\beta 33 X 3 . X 3+\beta 66 X 6 .
$$
$\mathrm{X} 6+\beta 13 \mathrm{X} 1 . \mathrm{X} 3+\beta 16 \mathrm{X} 1 . \mathrm{X} 6+\beta 36 \mathrm{X} 3 . \mathrm{X} 6$

Where $\mathrm{Y}$ is the response, $\beta 0$ is the model intercept, $\beta 1, \beta 3, \beta 6$ are the linear coefficients, $\beta 11, \beta 33, \beta 66$ are the quadratic coefficients, $\beta 13$, $\beta 16, \beta 36$ are the interaction coefficients and X1, X3 and X6 are the level of the independent variables. Each independent variable was coded as $X i$ according to the following equation:

$$
X i=\frac{(x i-x o)}{\Delta x i}
$$

$X i$ : Dimensional coded value for the independent variable

$x i$ : Real value of this variable at this coded value

$x o$ : Real value of this variable at the center point (zero level)

$\Delta x i$ : Step change value

Biodegradation processes in the twenty experiments (trials) were conducted in $250 \mathrm{~mL}$ of Erlenmeyer flasks containing $50 \mathrm{~mL}$ production medium at $37^{\circ} \mathrm{C}$ at $150 \mathrm{rpm}$ (New Brunswick Incubator Shaker, USA). Each trial was conducted in triplicates and the average of three readings was taken.

\section{Statistical analysis and three dimensional surface plots}

Statistica version 9.0 software was used to generate the statistical models, multiple regressions and creating of three dimensional surface plots. However, canonical and ridge analyses were carried out via RSM package ( $\mathrm{R}$ development Core team 2009), available from the Comprehensive R Archive Network at (http://CRAN.R-project.org/ package $=$ rsm) [43]

\section{Results}

\section{Optimizing feather bioconversion through B. licheniformis} SHG10

The process of feathers bioconversion directed by $B$. licheniformis SHG10 was evaluated by monitoring the levels of released soluble proteins and $\mathrm{NH}_{2}$-free amino groups. In the context of attaining optimized process for feather bioconversion, a two-step sequential statistical approach was anticipated. Table 1 displayed the experimental values along with the predicted values of both end products obtained upon screening the key determinants controlling the efficacy of feathers bioconversion through PBD. Detected levels of released soluble and $\mathrm{NH}_{2}$-free amino groups diverged from $0.02-0.245 \mathrm{mg} / \mathrm{mL}$ and 11-82 $\mu$ mole leucine/mL, respectively as shown in Table 1 . This divergence inferred the irreplaceable need for performing optimization to achieve the highest possible levels of these end products. Data gained from ANOVA (Table 3) revealed that the P-value and the F-value of the soluble proteins model were 0.003855 and 52.63, respectively. This model P-value inferred that the likelihood is only $0.385 \%$ that this model F-value could happen due to noise. However, the P-value and the F-value of the $\mathrm{NH}_{2}$-free amino groups' model were 0.068 and 7.04 , respectively (Table 3 ). These values imply that the probability is only $6.8 \%$ that the model F-value could exist due to nose. As a rule of thumb, significance of an estimate is inversely proportional to the $\mathrm{P}$-value [44]. Linear multiple regression analysis demonstrated that only four independent variables (feathers, yeast extract, $\mathrm{NH}_{4} \mathrm{Cl}$ and inoculum size) out of eight tested variables imposed significant effect at $\mathrm{P} \leq 0.006$ on the level of released soluble proteins as shown in Table 4. Conversely, only one independent variable (feathers) exhibited significant influence on the level of $\mathrm{NH}_{2}$-free amino groups at $\mathrm{P} \leq$ 0.02 . All estimates were calculated in terms of coded values and two polynomial equations of first order (Equations 4 and 5) were set to explain the linear effect forced by eight tested independent variables on feathers bioconversion.

$1^{\text {st }}$ order full polynomial equation for soluble protein model (Equation 4):

$\mathrm{Y} 1=0.109+0.0265 \mathrm{X} 1+0.0005 \mathrm{X} 2+0.019 \mathrm{X} 3-0.02267 \mathrm{X} 4+$ $0.0073 \mathrm{X} 5+0.0523 \mathrm{X} 6+0.006 \mathrm{X} 7-0.016 \mathrm{X} 8$ 
Citation: Embaby AM, Marey HS, Hussein A (2015) A Statistical-Mathematical Model to Optimize Chicken Feather Waste Bioconversion via Bacillus licheniformis SHG10: A Low Cost Effective and Ecologically Safe Approach. J Bioprocess Biotech 5: 231 doi:10.4172/2155-9821.1000231

Page 4 of 14

\begin{tabular}{|c|c|c|c|c|c|c|c|}
\hline \multirow{3}{*}{ Trial \# } & \multicolumn{3}{|c|}{ Independent variable } & \multicolumn{4}{|c|}{ Dependent variable } \\
\hline & \multirow{2}{*}{ Feather $\left(X_{1}\right)$} & \multirow{2}{*}{ Inoculum size $\left(X_{6}\right)$} & \multirow{2}{*}{ Yeast extract $\left(\mathbf{X}_{3}\right)$} & \multicolumn{2}{|c|}{ Soluble proteins $(\mathrm{mg} / \mathrm{mL})\left(\mathrm{Y}_{1}\right)$} & \multicolumn{2}{|c|}{$\mathrm{NH}_{2}$-free amino groups ( $\mu$ mole leucine $\left./ \mathrm{mL}\right)\left(\mathrm{Y}_{2}\right)$} \\
\hline & & & & Exp. $^{a}$ & Pred. $^{b}$ & Exp. $^{a}$ & Pred. $^{b}$ \\
\hline 1 & $-1(0.5)$ & $-1(6.0)$ & $-1(0.15)$ & 0.118 & 0.173 & 12.86 & 9.534 \\
\hline 2 & $-1(0.5)$ & $-1(6.0)$ & $1(0.45)$ & 0.119 & 0.102 & 36.65 & 39.346 \\
\hline 3 & $-1(0.5)$ & $1(10.0)$ & $-1(0.15)$ & 0.151 & 0.139 & 16.46 & 14.448 \\
\hline 4 & $-1(0.5)$ & $1(10.0)$ & $1(0.45)$ & 0.165 & 0.178 & 28.12 & 37.410 \\
\hline 5 & $1(1.5)$ & $-1(6.0)$ & $-1(0.15)$ & 0.266 & 0.269 & 62.12 & 53.954 \\
\hline 6 & $1(1.5)$ & $-1(6.0)$ & $1(0.45)$ & 0.196 & 0.223 & 46.55 & 49.687 \\
\hline 7 & $1(1.5)$ & $1(10.0)$ & $-1(0.15)$ & 0.234 & 0.267 & 80.55 & 78.979 \\
\hline 8 & $1(1.5)$ & $1(10.0)$ & $1(0.45)$ & 0.421 & 0.382 & 49.43 & 53.881 \\
\hline 9 & $-1.4(0.3)$ & $0(8.0)$ & $0(0.3)$ & 0.137 & 0.115 & 10.71 & 6.420 \\
\hline 10 & $1.4(1.7)$ & $0(8.0)$ & $0(0.3)$ & 0.336 & 0.325 & 47.05 & 49.044 \\
\hline 11 & $0(1.0)$ & $-1.4(5.2)$ & $0(0.3)$ & 0.269 & 0.227 & 33.65 & 38.151 \\
\hline 12 & $0(1.0)$ & $1.4(10.8)$ & $0(0.3)$ & 0.270 & 0.279 & 61.11 & 54.313 \\
\hline 13 & $0(1.0)$ & $0(8.0)$ & $-1.4(0.09)$ & 0.269 & 0.213 & 42.25 & 52.450 \\
\hline 14 & $0(1.0)$ & $0(8.0)$ & $1.4(0.51)$ & 0.231 & 0.244 & 70.30 & 55.750 \\
\hline 15 & $0(1.0)$ & $0(8.0)$ & $0(0.3)$ & 0.259 & 0.279 & 32.48 & 40.400 \\
\hline 16 & $0(1.0)$ & $0(8.0)$ & $0(0.3)$ & 0.284 & 0.279 & 46.50 & 40.400 \\
\hline 17 & $0(1.0)$ & $0(8.0)$ & $0(0.3)$ & 0.271 & 0.279 & 32.48 & 40.400 \\
\hline 18 & $0(1.0)$ & $0(8.0)$ & $0(0.3)$ & 0.284 & 0.279 & 46.50 & 40.400 \\
\hline 19 & $0(1.0)$ & $0(8.0)$ & $0(0.3)$ & 0.271 & 0.279 & 40.00 & 40.400 \\
\hline 20 & $0(1.0)$ & $0(8.0)$ & $0(0.3)$ & 0.259 & 0.279 & 40.00 & 40.400 \\
\hline
\end{tabular}

Values between in brackets are real values for the independent variables.

- Real values for the independent variables feather and yeast extract are taken in terms of \%w/v.

- Real values for the independent variable inoculum size are taken in terms of $\% \mathrm{v} / \mathrm{v}$ providing that one $\mathrm{ml}$ of culture contained $5.0 \times 10^{6} \mathrm{CFU} / \mathrm{mL}$.

- a: experimental values b: predicted values.

Table 2: CCD experiment with five levels of coded and real values for three factors along with the response.

\begin{tabular}{|c|c|c|c|c|c|c|c|c|c|c|}
\hline & \multicolumn{4}{|c|}{ Soluble proteins } & \multicolumn{4}{c|}{ NH $_{2}-$ free amino groups $^{*}$} \\
\cline { 2 - 10 } & df & SS & MS & F & Significance F & df & SS & MS & F & Significance F \\
\hline Regression & 8 & 0.046448 & 0.005806 & 52.63274 & 0.003855 & 8 & 3963.678 & 495.4597 & 7.0438 \\
\hline Residual & 3 & 0.000331 & 0.00011 & & & 3 & 211.0203 & 70.3401 \\
\hline Total & 11 & 0.046779 & & & & 11 & 4174.698 & \\
\hline
\end{tabular}

Table 3: ANOVA for experimental results of PBD.

$1^{\text {st }}$ order full polynomial equation for $\mathrm{NH}_{2}$-free amino groups model (Equation 5):

$\mathrm{Y} 2=45.707+12.159 \mathrm{X} 1-0.9925 \mathrm{X} 2+5.61 \mathrm{X} 3+9.33 \mathrm{X} 4+4.834 \mathrm{X} 5+$ $1.464 \mathrm{X} 6+1.464 \mathrm{X} 6-6.0008 \mathrm{X} 7-1.4058 \mathrm{X} 8$

With respect to the remaining independent variables that did not exert significant impact on feathers bioconversion; they were either added at their initial lowest coded levels (e.g., $\mathrm{K}_{2} \mathrm{HPO}_{4}$ ) or omitted from the medium (e.g., casamino acids and peptone) in the next experiments. In order to generate a low cost effective optimized medium prompting simultaneous high productivity of both end products, only three key determinants namely feathers, yeast extract and inoculum size were chosen to conduct the next experiment in the sequential statistical optimization plan.

In an attempt to achieve the optimal levels of each key determinant controlling the efficiency of feathers bioconversion along with the possible maximal levels of the process outcome, RSM in terms of CCD was applied. ANOVA results (Table 5) addressed that the P-value and the F-value for the soluble proteins model were 0.0018 and 7.65 , respectively. This means that the possibility is $0.18 \%$ that this F-value could happen due to noise. Alternatively, the P-value and the F-value for the $\mathrm{NH}_{2}$-free amino groups' model were 0.0022 and 7.31, respectively. This deduced that the chance is $0.22 \%$ that this F-value could exist due to noise. With regard to soluble proteins, data derived from multiple non-linear regression (Table 6) revealed that the independent variable feathers imposed significant effectuation on the efficiency of feathers bioconversion in two forms of interactions (linear and quadratic ones) at $\mathrm{P}<0.05$. Whilst, the other two independent variables; yeast extract and inoculum size showed significant influence on the process only in one form of interaction (cross interaction) at $\mathrm{P}<0.05$. Concerning $\mathrm{NH}_{2}$-free amino groups model, anchored in data of multiple non-linear regression (Table 5), feathers and inoculum size presented significant effect in linear and cross interaction manners at $\mathrm{P}<0.05$. While, yeast extract demonstrated significant impact in a quadratic manner at $\mathrm{P}$ $\leq 0.05$. Regression coefficients were set based on coded values and a second polynomial equation from the second order (Equations 6 and 7) was fitted to explore all possible interactions of the independent variables that could exert significant impact on feathers bioconversion.

$2^{\text {nd }}$ order full polynomial equation for soluble proteins model (Equation 6)

$\mathrm{Y} 2=40.4+15.00 \mathrm{X} 1+5.77 \mathrm{X} 6+1.178 \mathrm{X} 3-6.46 \mathrm{X} 1 . \mathrm{X} 1+2.97 \mathrm{X} 6 . \mathrm{X} 6$ $+6.99 \mathrm{X} 3 . \mathrm{X} 3+1.53 \mathrm{X} 1 . \mathrm{X} 6-8.51 \mathrm{X} 1 \mathrm{X} 3-5.21 \mathrm{X} 3 . \mathrm{X} 6$

$2^{\text {nd }}$ order full polynomial equation for $\mathrm{NH}_{2}$-free amino groups model (Equation 7):

$\mathrm{Y} 2=40.4+15.22 \mathrm{X} 1+5.77 \mathrm{X} 6+1.178 \mathrm{X} 3-6.46 \mathrm{X} 1 . \mathrm{X} 1+2.97 \mathrm{X} 6 . \mathrm{X} 6$ $+6.99 \mathrm{X} 3 . \mathrm{X} 3+1.53 \mathrm{X} 1 \mathrm{X} 6-8.51 \mathrm{X} 1 . \mathrm{X} 3-5.21 \mathrm{X} 3 . \mathrm{X} 6$ 
Citation: Embaby AM, Marey HS, Hussein A (2015) A Statistical-Mathematical Model to Optimize Chicken Feather Waste Bioconversion via Bacillus licheniformis SHG10: A Low Cost Effective and Ecologically Safe Approach. J Bioprocess Biotech 5: 231 doi:10.4172/2155-9821.1000231

Page 5 of 14

\begin{tabular}{|c|c|c|c|c|c|c|c|c|c|}
\hline \multirow{3}{*}{$\begin{array}{l}\text { Independent } \\
\text { variable }\end{array}$} & \multirow{2}{*}{$\begin{array}{c}\text { Coefficient } \\
\text { Symbol }\end{array}$} & \multicolumn{4}{|c|}{ Soluble proteins ${ }^{(1)}\left(Y_{1}\right)$} & \multicolumn{4}{|c|}{$\mathrm{NH}_{2}$-free amino groups ${ }^{(2)}\left(\mathrm{Y}_{2}\right)$} \\
\hline & & Estimate & t-value & P-value & $\%$ confidence & Estimate & t-value & P-value & $\%$ confidence \\
\hline & B0 & 0.1095 & 24.1899 & $6.99 \mathrm{E}-05^{*}$ & 99.99 & 45.7075 & 19.1920 & $0.000327^{\star}$ & 99.97 \\
\hline $\mathrm{X}_{1}:$ Feather $\%(\mathrm{~W} / \mathrm{V})$ & B1 & 0.0265 & 5.85419 & $0.00274^{*}$ & 99.726 & 12.1592 & 5.10548 & $0.015578^{*}$ & 98.44 \\
\hline $\mathrm{X}_{2}:$ Peptone \% (W/V) & B2 & 0.0005 & 0.11045 & 0.118777 & & -0.9925 & -0.416 & 0.807205 & \\
\hline $\mathrm{X}_{3}:$ Yeast extract $\%(\mathrm{~W} / \mathrm{V})$ & B3 & 0.0190 & 4.19734 & $0.006028^{*}$ & 99.3972 & 5.61083 & 2.35592 & 0.106506 & \\
\hline $\mathrm{X}_{4}: \mathrm{NH}_{4} \mathrm{Cl} \%(\mathrm{~W} / \mathrm{V})$ & B4 & -0.02267 & -5.0073 & $0.002601^{*}$ & 98.9103 & 9.33083 & 3.917901 & 0.030684 & \\
\hline $\mathrm{X}_{5}:$ Time (hrs) & B5 & 0.007333 & 1.62002 & 0.010897 & 98.9103 & 4.83417 & 2.02981 & 0.137648 & \\
\hline $\mathrm{X}_{6}:$ Inoculum size $\%(\mathrm{~V} / \mathrm{V})$ & B6 & 0.052333 & 11.5611 & $0.001033^{*}$ & 99.8967 & 1.4641 & 0.61479 & 0.575616 & \\
\hline $\mathrm{X}_{7}:$ Casamino acids $\%(\mathrm{~W} / \mathrm{V})$ & B7 & 0.0060 & 1.32547 & 0.978258 & & -6.00083 & -2.51968 & 0.088292 & \\
\hline $\mathrm{X}_{8}: \mathrm{K}_{2} \mathrm{HPO}_{4} \%(\mathrm{~W} / \mathrm{V})$ & B8 & -0.01067 & -2.356 & 0.898196 & & -1.40583 & -0.59029 & 0.617889 & \\
\hline
\end{tabular}

- Highlighted significant model terms are taken at $P \leq 0.006$ for the soluble protein model.

- Highlighted significant model terms are taken at $P \leq 0.02$ for the $\mathrm{NH}_{2}$-free amino groups model.

(1): $R^{2}=0.99$ and adjusted $R^{2}=0.97$

(2): $R^{2}=0.95$ and adjusted $R^{2}=0.85$

Table 4: Regression summary for full polynomial equation for end products of feather biodegradation upon using PBD.

\begin{tabular}{|c|c|c|c|c|c|c|c|c|c|c|}
\hline & \multicolumn{5}{|c|}{ Soluble proteins } & \multicolumn{5}{|c|}{$\mathrm{NH}_{2}$-free amino groups } \\
\hline & df & SS & MS & $\mathbf{F}$ & $\underset{F}{\text { Significance }}$ & df & ss & MS & $\mathbf{F}$ & $\underset{F}{\text { Significance }}$ \\
\hline Regression & 9 & 0.093857 & 0.010429 & 7.6557 & 0.001894 & 9 & 5346.582 & 594.0647 & 7.313814 & 0.002273 \\
\hline Residual & 10 & 0.013622 & 0.001362 & & & 10 & 812.2502 & 81.22502 & & \\
\hline Total & 19 & 0.107479 & & & & 19 & 6158.832 & & & \\
\hline
\end{tabular}

Table 5: ANOVA for experimental results of CCD.

\begin{tabular}{|c|c|c|c|c|c|c|c|c|c|}
\hline \multirow{3}{*}{$\begin{array}{l}\text { Independent } \\
\text { variable }\end{array}$} & \multirow[t]{2}{*}{ Coefficient Symbol } & \multicolumn{4}{|c|}{ Soluble proteins ${ }^{(1)}\left(Y_{1}\right)$} & \multicolumn{4}{|c|}{$\mathrm{NH}_{2}$-free amino groups ${ }^{(2)}\left(\mathrm{Y}_{2}\right)$} \\
\hline & & Estimate & t-value & P-value & \%confidence & Estimate & t-value & $P$-value & \%confidence \\
\hline & BO & 0.278816 & 19.28318 & 3.07E-09* & 99.99 & 40.40009 & 11.442 & $4.56 \mathrm{E}-07^{*}$ & 99.99 \\
\hline Feather $\left(\mathrm{X}_{1}\right)$ & $B 1$ & 0.075021 & 6.879394 & $4.3 \mathrm{E}-05^{*}$ & 99.99 & 15.22281 & 5.7165 & $0.000194^{*}$ & 99.99 \\
\hline Inoculum size $\left(\mathrm{X}_{6}\right)$ & $B 6$ & 0.018603 & 1.705866 & 0.118844 & & 5.77216 & 2.1675 & 0.055394 & 95.00 \\
\hline Yeast extract $\left(\mathrm{X}_{3}\right)$ & B3 & 0.010944 & 1.003568 & 0.339252 & & 1.178679 & 0.4426 & 0.667458 & \\
\hline $\mathrm{X}_{1}^{2}$ & B11 & -0.02982 & -2.35315 & $0.040423^{\star}$ & 96.00 & -6.46324 & -2.088 & 0.063244 & \\
\hline$X_{6}^{2}$ & $B 66$ & -0.01298 & -1.02437 & 0.329804 & & 2.975538 & 0.9617 & 0.358881 & \\
\hline $\mathrm{X}_{3}{ }^{2}$ & B33 & -0.02583 & -2.01049 & 0.072116 & & 6.990076 & 2.2284 & 0.049982 & 95.10 \\
\hline$x_{1} \cdot x_{6}$ & B16 & 0.020707 & 1.540874 & 0.154372 & & 1.532481 & 0.4670 & 0.650503 & \\
\hline $\mathrm{X}_{1} \cdot \mathrm{X}_{3}$ & $B 13$ & 0.006293 & 0.468305 & 0.649607 & & -8.51998 & -2.596 & 0.026656 & 97.40 \\
\hline$X_{3} \cdot X_{6}$ & B36 & 0.040207 & 2.991949 & $0.013529^{*}$ & 98.65 & -5.20752 & -1.587 & 0.14361 & \\
\hline
\end{tabular}

- Highlighted significant model terms are taken at $P<0.05$ for the soluble protein model.

- Highlighted significant model terms are taken at $P \leq 0.06$ for the $\mathrm{NH}_{2}$-free amino groups' model

(1): $R^{2}=0.87$ and adjusted $R^{2}=0.76$

(2): $R^{2}=0.87$ and adjusted $R^{2}=0.75$

Table 6: Regression summary for full polynomial equation for end products of feather biodegradation upon using CCD

Canonical analysis was performed to determine the overall shape of the response for both models that in turn determines whether the stationary point is maximum, minimum or saddle point. Eigen-values and eigenvectors in the matrix of second order are used to describe shape of the response. Eigen vectors could delimit the directions of principle orientation for the surface whereas; surface shape in these directions could be inferred from signs and magnitude of Eigenvalues. Mathematical indications and concept of Eigen values were explained previously in two rules by Myers 1976 [45]. Downward and upward curvatures of the response could be inferred from negative and positive Eigen values, respectively (as stated in Myers $1^{\text {st }}$ rule). Whilst, the magnitude of an Eigen value regardless its sign reflects that the curvature of the response would be in the associated directions (Myers $2^{\text {nd }}$ rule). Present data imply that soluble proteins model has Eigen values of $\left(\lambda_{1}=0.0042, \lambda_{6}=-0.031\right.$ and $\left.\lambda_{3}=-0.034\right)$. These Eigen values with mixed signs indicated that the predicted stationary point for soluble protein model is neither maximum nor minimum (i.e., saddle point). Alternatively, the response shape had a pronounced curvature in the directions of $\mathrm{X}_{6}$ and $\mathrm{X}_{3}$ regarding the magnitudes of their Eigen values of 0.031 and 0.034 , respectively. The predicted stationary point in terms of coded levels was at $\left(\mathrm{X}_{1}=-0.44, \mathrm{X}_{6}=-3.9\right.$ and $\left.\mathrm{X}_{3}=-3.097\right)$. It is clear that this stationary point is located outside the explored domain. Consequently, any predictions at this point are unreliable. It does make sense to employ ridge analysis here as a powerful mathematical tool to look for the stationary point since the predicted stationary point is at some distance away from the explored domain. In other words, it is a must in this case to start form the center of the original design rather than from the saddle point to search for the reliable stationary point. Ridge analysis calculates the estimated ridge of optimum response from a set of predictor combinations at radius $\mathrm{d}$ with steeply increasing radii starting from the origin $[46,47]$. Table 7 illustrated the estimated maximum response as predicted from the steepest ascent path using ridge analysis. Data derived from ridge analysis revealed that the more rising is in the ridge the more elevation is in the response without reaching to a stationary point (threshold level). A at distance of 2.1, a predicted stationary point of $0.404 \mathrm{mg} / \mathrm{mL}$ soluble protein was achieved upon 
Citation: Embaby AM, Marey HS, Hussein A (2015) A Statistical-Mathematical Model to Optimize Chicken Feather Waste Bioconversion via Bacillus licheniformis SHG10: A Low Cost Effective and Ecologically Safe Approach. J Bioprocess Biotech 5: 231 doi:10.4172/2155-9821.1000231

Page 6 of 14

using the predictor combination: $\mathrm{X}_{1}=1.212, \mathrm{X}_{6}=1.418$ and $\mathrm{X}_{3}=0.977$. This predicted stationary point is located inside the domain. Upon moving to further distances ( $\mathrm{d}=2.2$ to 2.9 ) along the rising ridge there is an increase in the estimated response corresponding to estimated levels of $\mathrm{X}_{1}, \mathrm{X}_{6}$ and $\mathrm{X}_{3}$ outside the domain (Table 7). In order to determine the stationary point at which the maximum estimated response could be achieved, three sets of predictor's combinations of $\mathrm{X}_{1}, \mathrm{X}_{6}$ and $\mathrm{X}_{3}$ at three corresponding distances 2.2, 2.6 and 2.9 were tried experimentally. Laboratory experimental data inferred that, there is a little bit increase in the calculated maximum response upon moving along the rising ridge from $d=2.2$ to $d=2.9$. From the standpoint of cost effectiveness, using the lowest set of predictor's combination to achieve the maximal possible response would greatly alleviate the cost of the whole process upon scaling up. As a matter of fact, the more residual undegraded feather would exist at the end of the bioprocess, the more cost would be added in downstream processing to remove it. A compromise between the experimental yield (validated in the lab) imposed by the predictor's combination along with the added cost in each step involved in the bioprocess resulted in selection of the predictor's combination at $\mathrm{d}=2.1$ in terms of coded values/real values $\mathrm{X}_{1}=1.212 / 1.6 \%(\mathrm{w} / \mathrm{v}), \mathrm{X}_{6}=$ $1.418 / 10.8 \%(\mathrm{v} / \mathrm{v})$ and $\mathrm{X}_{3}=0.977 / 0.45 \%(\mathrm{w} / \mathrm{v})$ to achieve the maximal response $0.404 \mathrm{mg} / \mathrm{mL}$ of soluble proteins. Upon compensation in equation 6 after removal of the non-significant model terms with the predicted values (in terms of coded values) included in the predictor combination set at a distance of 2.1 of ridge analysis, the yield of soluble protein would be $0.39 \mathrm{mg} / \mathrm{mL}$.

On the other hand, $\mathrm{NH}_{2}$-free amino groups model has Eigen values of $\left(\lambda_{1}=9.29, \lambda_{6}=1.8\right.$ and $\left.\lambda_{3}=-8.8\right)$. The response shape had a pronounced curvature in the directions of $\mathrm{X}_{1}$ and $\mathrm{X}_{3}$ regarding the magnitudes of their Eigen values of 9.29 and 8.8, respectively. These mixed Eigen values with mixed signs pointed out that the predicted stationary point for $\mathrm{NH}_{2}$-free amino groups model is saddle point (neither maximum nor minimum). However, the predicted stationary point (43.56 $\mu$ mole leucine $/ \mathrm{mL})$ in terms of coded values was at $\left(\mathrm{X}_{1}=0.79, \mathrm{X}_{6}=-\right.$ 1.47 and $\mathrm{X}_{3}=0.046$ ). It is evident that this predicted stationary point is positioned inside the explored domain. Based on this evidence, it is logic to search for the reliable stationary point starting from the saddle point rather than from the center. This will be obtained via following the most steeply rising ridge in both directions, i.e. canonical path function (Table 8 ). At a distance of -2.2 , the predictor combination set in terms of coded values $\left(\mathrm{X}_{1}=1.476, \mathrm{X}_{6}=-0.811\right.$ and $\left.\mathrm{X}_{3}=-1.936\right)$ resulted in achieving a predicted stationary point of $88.49 \mu$ mole leucine $/ \mathrm{mL}$. By moving to further distance along the negative direction of the canonical path, a rising ridge of the level of $\mu$ mole leucine $/ \mathrm{mL}$ was noticed without reaching to a stationary point (threshold level). Testing different predicator combinations of $\mathrm{X}_{1}, \mathrm{X}_{6}$ and $\mathrm{X}_{3}$ did not result in higher appreciable levels of the response experimentally. By looking

\begin{tabular}{|c|c|c|c|c|c|c|c|c|c|}
\hline \multirow[t]{2}{*}{ Distance (d) } & \multicolumn{3}{|c|}{ Coded values of independent variables } & \multirow[t]{2}{*}{$\begin{array}{l}\text { Estimated } \mathbf{Y}_{1} \\
\text { response }\end{array}$} & \multirow[t]{2}{*}{$\begin{array}{l}\text { Distance } \\
\text { (d) }\end{array}$} & \multicolumn{3}{|c|}{ Coded values of independent variables } & \multirow{2}{*}{$\begin{array}{l}\text { Estimated } \mathbf{Y}^{2} \\
\text { response }\end{array}$} \\
\hline & $X_{1}$ & $X_{6}$ & $X_{3}$ & & & $X_{1}$ & $X_{6}$ & $\mathbf{X}_{3}$ & \\
\hline 0.0 & 0.000 & 0.000 & 0.000 & 0.277 & 0.0 & 0.000 & 0.000 & 0.000 & 40.444 \\
\hline 0.1 & 0.093 & 0.034 & 0.012 & 0.284 & 0.1 & 0.094 & 0.032 & 0.009 & 42.094 \\
\hline 0.2 & 0.183 & 0.074 & 0.030 & 0.291 & 0.2 & 0.186 & 0.074 & 0.003 & 43.648 \\
\hline 0.3 & 0.269 & 0.12 & 0.055 & 0.297 & 0.3 & 0.271 & 0.126 & -0.025 & 45.124 \\
\hline 0.4 & 0.350 & 0.173 & 0.085 & 0.304 & 0.4 & 0.346 & 0.184 & -0.078 & 46.593 \\
\hline 0.5 & 0.427 & 0.231 & 0.122 & 0.310 & 0.5 & 0.410 & 0.241 & -0.152 & 48.120 \\
\hline 0.6 & 0.498 & 0.294 & 0.162 & 0.316 & 0.6 & 0.466 & 0.294 & -0.237 & 49.767 \\
\hline 0.7 & 0.564 & 0.360 & 0.207 & 0.322 & 0.7 & 0.515 & 0.343 & -0.328 & 51.552 \\
\hline 0.8 & 0.625 & 0.429 & 0.254 & 0.327 & 0.8 & 0.560 & 0.387 & -0.420 & 53.472 \\
\hline 0.9 & 0.683 & 0.500 & 0.304 & 0.333 & 0.9 & 0.602 & 0.429 & -0.513 & 55.562 \\
\hline 1.0 & 0.738 & 0.573 & 0.356 & 0.339 & 1.0 & 0.642 & 0.469 & -0.606 & 57.828 \\
\hline 1.1 & 0.789 & 0.647 & 0.410 & 0.344 & 1.1 & 0.680 & 0.508 & -0.699 & 60.265 \\
\hline 1.2 & 0.838 & 0.722 & 0.464 & 0.350 & 1.2 & 0.718 & 0.545 & -0.792 & 62.891 \\
\hline 1.3 & 0.885 & 0.798 & 0.519 & 0.356 & 1.3 & 0.754 & 0.581 & -0.885 & 65.683 \\
\hline 1.4 & 0.931 & 0.875 & 0.576 & 0.362 & 1.4 & 0.790 & 0.617 & -0.978 & 68.683 \\
\hline 1.5 & 0.974 & 0.951 & 0.631 & 0.367 & 1.5 & 0.825 & 0.651 & -1.070 & 71.821 \\
\hline 1.6 & 1.015 & 1.026 & 0.687 & 0.373 & 1.6 & 0.860 & 0.686 & -1.162 & 75.175 \\
\hline 1.7 & 1.055 & 1.103 & 0.743 & 0.379 & 1.7 & 0.894 & 0.719 & -1.254 & 78.682 \\
\hline 1.8 & 1.096 & 1.182 & 0.802 & 0.385 & 1.8 & 0.928 & 0.753 & -1.35 & 82.404 \\
\hline 1.9 & 1.135 & 1.259 & 0.859 & 0.391 & 1.9 & 0.962 & 0.786 & -1.438 & 86.308 \\
\hline 2.0 & 1.173 & 1.336 & 0.917 & 0.397 & 2.0 & 0.995 & 0.819 & -1.530 & 90.391 \\
\hline 2.1 & 1.212 & 1.418 & 0.977 & 0.404 & 2.1 & 1.029 & 0.851 & -1.621 & 94.642 \\
\hline 2.2 & 1.246 & 1.490 & 1.032 & 0.409 & 2.2 & 1.062 & 0.883 & -1.712 & 99.064 \\
\hline 2.3 & 1.282 & 1.567 & 1.089 & 0.416 & 2.3 & 1.095 & 0.916 & -1.804 & 103.736 \\
\hline 2.4 & 1.319 & 1.649 & 1.151 & 0.422 & 2.4 & 1.128 & 0.948 & -1.895 & 108.54 \\
\hline 2.5 & 1.352 & 1.723 & 1.206 & 0.428 & 2.5 & 1.160 & 0.979 & -1.986 & 113.506 \\
\hline 2.6 & 1.387 & 1.801 & 1.264 & 0.435 & 2.6 & 1.193 & 1.011 & -2.077 & 118.702 \\
\hline 2.7 & 1.423 & 1.881 & 1.324 & 0.442 & 2.7 & 1.225 & 1.043 & -2.168 & 124.066 \\
\hline 2.8 & 1.452 & 1.947 & 1.374 & 0.447 & 2.8 & 1.258 & 1.074 & -2.259 & 129.625 \\
\hline 2.9 & 1.487 & 2.029 & 1.435 & 0.454 & 2.9 & 1.290 & 1.106 & -2.350 & 135.372 \\
\hline 3.0 & 1.520 & 2.107 & 1.494 & 0.461 & 3.0 & 1.323 & 1.137 & -2.441 & 141.315 \\
\hline
\end{tabular}

(1): Soluble proteins in terms of $\mathrm{mg} / \mathrm{mL}$ (2): $\mathrm{NH}_{2}$-free amino groups in terms of $\mu$ mole leucine $/ \mathrm{mL}$.

Table 7: Estimated ridge of maximum response $Y_{1}$ and $Y_{2}$. 
Citation: Embaby AM, Marey HS, Hussein A (2015) A Statistical-Mathematical Model to Optimize Chicken Feather Waste Bioconversion via Bacillus licheniformis SHG10: A Low Cost Effective and Ecologically Safe Approach. J Bioprocess Biotech 5: 231 doi:10.4172/2155-9821.1000231

Page 7 of 14

\begin{tabular}{|c|c|c|c|c|c|c|c|c|c|}
\hline \multirow{2}{*}{$\begin{array}{c}\text { Distance } \\
\text { (d) }\end{array}$} & \multicolumn{3}{|c|}{ Coded values of independent variables } & \multirow{2}{*}{$\begin{array}{c}\text { Estimated } Y_{2} \\
\text { response }\end{array}$} & \multirow{2}{*}{$\begin{array}{l}\text { Distance } \\
\text { (d) }\end{array}$} & \multicolumn{3}{|c|}{ Coded values of independent variables } & \multirow{2}{*}{$\begin{array}{c}\text { Estimated } Y_{2} \\
\text { response }\end{array}$} \\
\hline & $X_{1}$ & $X_{6}$ & $\mathbf{X}_{3}$ & & & $x_{1}$ & $X_{6}$ & $\mathbf{X}_{3}$ & \\
\hline-3.0 & 1.700 & -0.571 & -2.657 & 127.120 & 0.0 & 0.787 & -1.472 & 0.046 & 43.563 \\
\hline-2.9 & 1.695 & -0.601 & 2.567 & 121.652 & 0.3 & 0.693 & -1.562 & 0.316 & 44.398 \\
\hline-2.8 & 1.664 & -0.631 & -2.477 & 116.370 & 0.6 & 0.599 & -1.652 & 0.586 & 46.90 \\
\hline-2.7 & 1.632 & -0.661 & -2.387 & 111.256 & 0.9 & 0.505 & -1.742 & 0.857 & 51.089 \\
\hline-2.6 & 1.601 & -0.691 & -2.297 & 106.34 & 1.2 & 0.411 & -1.832 & 1.127 & 56.934 \\
\hline-2.5 & 1.570 & -0.721 & -2.206 & 101.576 & 1.5 & 0.317 & -1.922 & 1.397 & 64.44 \\
\hline-2.4 & 1.539 & -0.751 & -2.116 & 97.035 & 1.8 & 0.223 & -2.012 & 1.668 & 73.660 \\
\hline-2.3 & 1.507 & -0.781 & -2.026 & 92.667 & 2.1 & 0.129 & -2.102 & 1.938 & 84.515 \\
\hline-2.2 & 1.476 & -0.811 & -1.936 & 88.497 & 2.2 & 0.098 & -2.132 & 2.028 & 88.500 \\
\hline-2.1 & 1.445 & -0.841 & -1.846 & 84.512 & 2.3 & 0.066 & -2.16 & 2.118 & 92.684 \\
\hline-2.0 & 1.413 & -0.871 & -1.756 & 80.70 & 2.4 & 0.035 & -2.192 & 2.208 & 97.039 \\
\hline-1.8 & 1.351 & -0.931 & -1.576 & 73.657 & 2.6 & -0.028 & -2.252 & 2.388 & 106.320 \\
\hline-1.6 & 1.288 & -0.991 & -1.396 & 67.344 & 2.8 & -0.090 & -2.313 & 2.568 & 116.343 \\
\hline-1.4 & 1.225 & -1.051 & -1.215 & 61.750 & & & & & \\
\hline-1.2 & 1.163 & -1.111 & -1.035 & 56.932 & & & & & \\
\hline-1.0 & 1.100 & -1.171 & -0.855 & 52.849 & & & & & \\
\hline-0.6 & 0.975 & -1.291 & -0.495 & 46.911 & & & & & \\
\hline-0.2 & 0.84 & -1.411 & -0.134 & 43.934 & & & & & \\
\hline
\end{tabular}

$\mathrm{Y}_{2}$ was estimated in terms of $\mu$ mole leucine/mL.

Table 8: Estimated maximum response for $\mathrm{NH}_{2}$-free amino groups using canonical path function.

at the predictor combination $\left(\mathrm{X}_{1}=0.098, \mathrm{X}_{6}=-2.13\right.$ and $\left.\mathrm{X}_{3}=2.03\right)$ at the same distance (2.2) in the opposite direction, we can notice that this predictor combination is not reliable absolutely. The more the level is from feathers in usage the more the level is from the response as deduced from multiple non-linear regression. Based on these data, the predictor combination $\left(\mathrm{X}_{1}=1.476, \mathrm{X}_{6}=-0.811\right.$ and $\left.\mathrm{X}_{3}=-1.936\right)$ was chosen to be tried experimentally. It did impose a response level of $104 \mu$ mole leucine/mL. Alternatively, ridge analysis was performed as well in an attempt to further confirm the reliability of the predictor combination set for the maximal response $\mathrm{NH}_{2}$-free amino groups (as shown in Table 7). By moving along the rising ridge, an increase in the response was obtained without reaching to a stationary point (Table 7). At a distance of 2.3, the predictor combination $\left(\mathrm{X}_{1}=1.095\right.$, $\mathrm{X}_{6}=0.916$ and $\left.\mathrm{X}_{3}=-1.8\right)$ yielded a level of $103.73 \mu$ mole leucine $/ \mathrm{mL}$ experimentally. Testing other predictor combinations along the rising ridge experimentally did not result in perceivable levels of the response. Based on canonical and ridge analyses, two predictors' combination sets: $\left(\mathrm{X}_{1}=1.476, \mathrm{X}_{6}=-0.811\right.$ and $\left.\mathrm{X}_{3}=-1.936\right)$ and $\left(\mathrm{X}_{1}=1.095, \mathrm{X}_{6}=0.916\right.$ and $X_{3}=-1.8$ ), respectively with a maximal response of 104 and 103.73 $\mu$ mole leucine $/ \mathrm{mL}$ experimentally were obtained. From the standpoint of low cost effectiveness, the predictor combination set from ridge analysis at a distance of 2.3 in terms of real values $\left(\mathrm{X}_{1}=1.55 \%(\mathrm{w} / \mathrm{v})\right.$, $\mathrm{X}_{6}=9.8 \%(\mathrm{v} / \mathrm{v})$ and $\left.\mathrm{X}_{3}=0.03 \%(\mathrm{w} / \mathrm{v})\right)$ was selected to carry out an optimized process of feather bioconversion in terms of $\mathrm{NH}_{2}$-free amino groups as a response. Upon compensation in equation 7 after removal of the non-significant model terms with the predicted values (in terms of coded values) included in the predictor combination set at a distance of 2.3 of ridge analysis, the yield of $\mathrm{NH}_{2}$-free amino groups would be $101 \mu$ mole leucine $/ \mathrm{mL}$.

Further exploration of the nature of the response shape has been carried out through depicting of three dimensional surface plots. Figures 1a-1c demonstrated that the three dimensional surface plots of the response soluble proteins at optimal values of the independent variables; yeast extract, inoculum size and feathers, respectively. It is obvious that, the three independent variables exerted the highest possible predicted level of the output soluble proteins at their nearby highest levels (at the design constrains). Deductions derived from three dimensional surface plots greatly emphasized the regression results of both $1^{\text {st }}$ order and $2^{\text {nd }}$ order polynomial models. With reference to $\mathrm{NH}_{2}$-free amino groups, only one independent variable had significant impact. The three dimensional surface plots (depicted in Figures 2a2c) conferred that the only independent variable exerting highest significant influence on the process outcome ( $\mathrm{NH}_{2}$-free amino groups) was feathers. Similarly, deductions derived from Figures $2 \mathrm{a}-2 \mathrm{c}$ greatly verified the regression results of the $1^{\text {st }}$ polynomial model. The highest possible levels of $\mathrm{NH}_{2}$-free amino groups would occur at the highest level of feathers $1.55 \%(\mathrm{w} / \mathrm{v})$.

Furthermore, the efficiency of feather bioconversion directed by $B$. licheniformis SHG10 was evaluated via visualizing the physical changes occurring in the feather shape after two days of incubation. Figure 3 demonstrated that almost all feather body disappeared except feather shaft.

\section{Model validation}

On top and above, both selected predictor combinations mentioned above of both process outputs (soluble proteins and $\mathrm{NH}_{2}$-free amino groups) were experimentally validated in the laboratory to judge the model aptness. Experimental data verified that predicted values represented $100 \%$ of the experimental ones for both models. This in turn implied that the applied model had a high precision and adequacy to explain the relationship between the process output (dependent variable) and the independent variables.

\section{MALDI-TOF-MS spectrum of SHG10 FH}

SHG10 FH protein spectrum on MALDI-TOF-MS showed soluble proteins in the range from $140 \mathrm{Da} / \mathrm{z}$ to $733 \mathrm{Da} \mathrm{m} / \mathrm{z}$ (Figure 4).

\section{Amino acids profile of SHG10 FH}

Efficiency of feather bioconversion directed by B. licheniformis SHG10 was further evaluated with monitoring the levels of released 


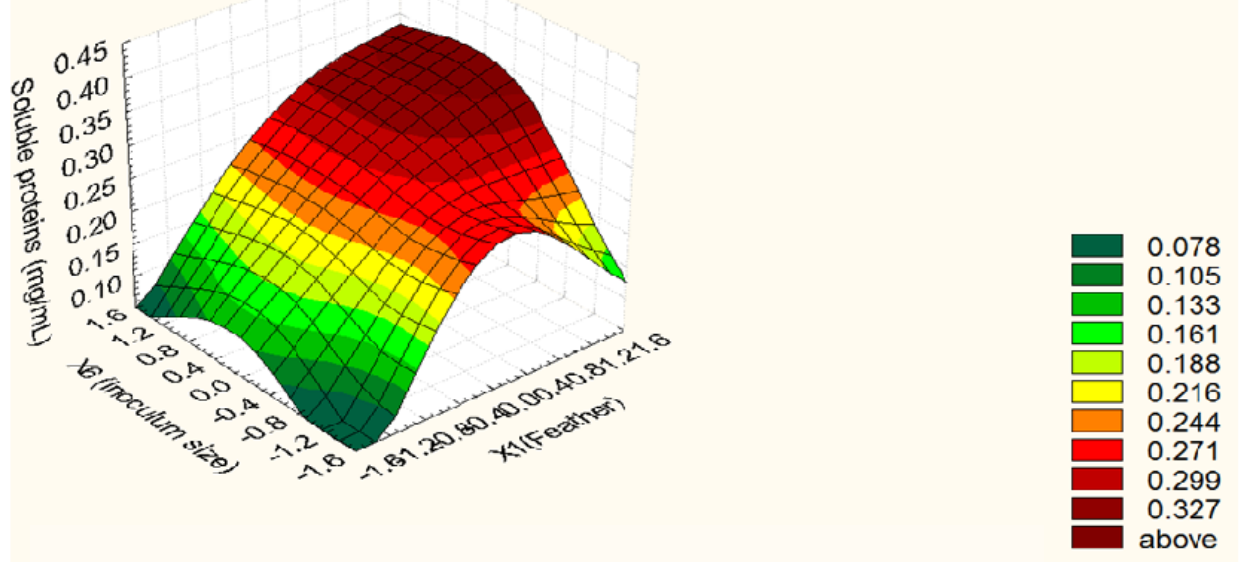

Figure 1a: Three dimensional surface plot for the dependent variable soluble proteins vs. feather and inoculum size.

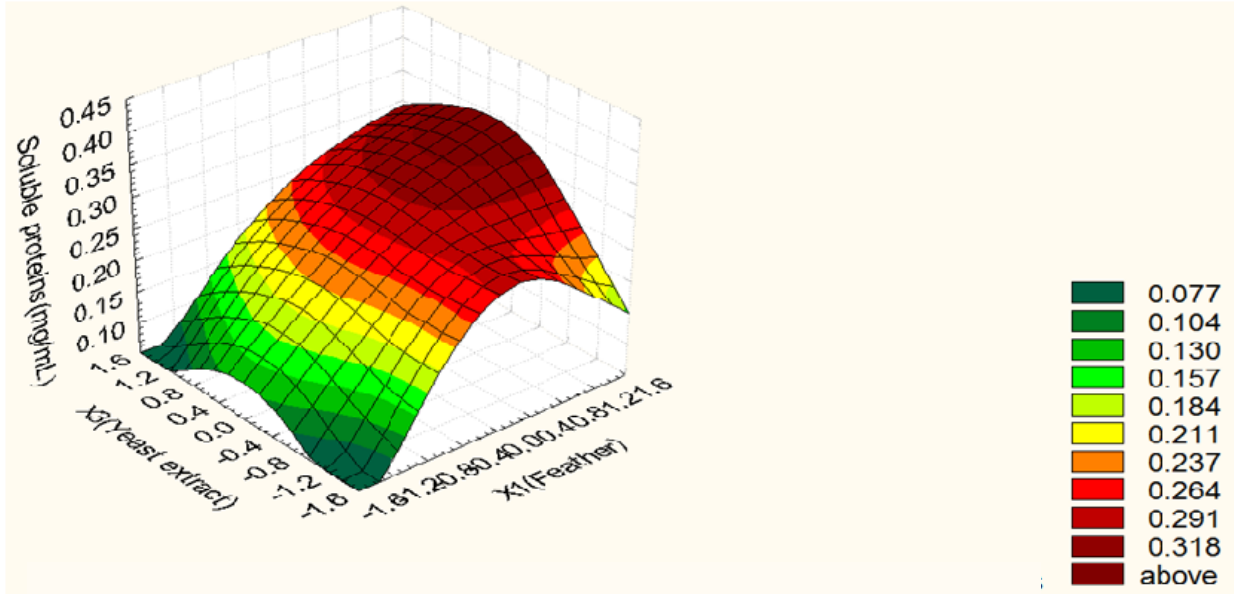

Figure 1b: Three dimensional surface plot for the dependent variable soluble proteins vs. feather and yeast extract.

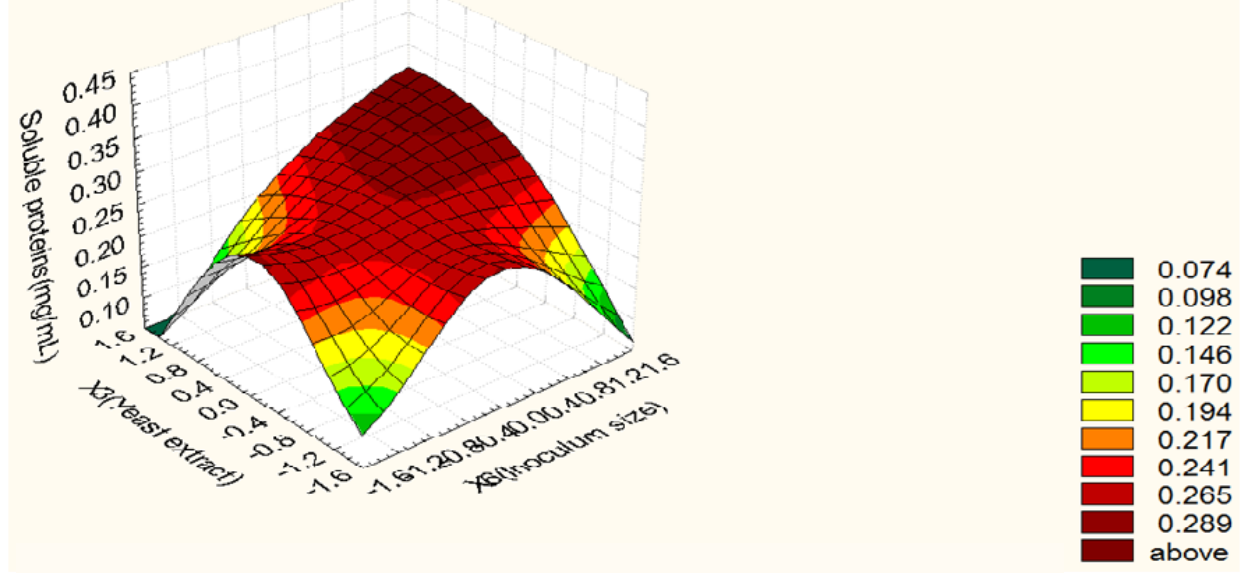

Figure 1c: Three dimensional surface plot for the dependent variable soluble proteins vs. inoculum size and yeast extract. 


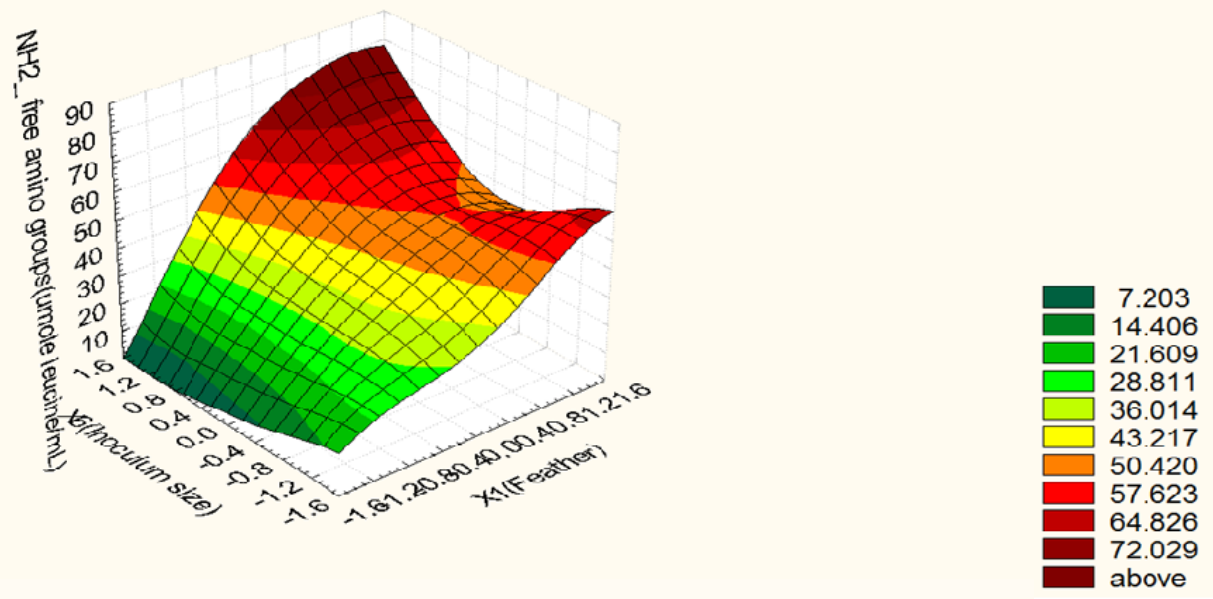

Figure 2a: Three dimensional surface plot for the dependent variable $\mathrm{NH}_{2}$-free amino groups vs. feather and inoculum size.

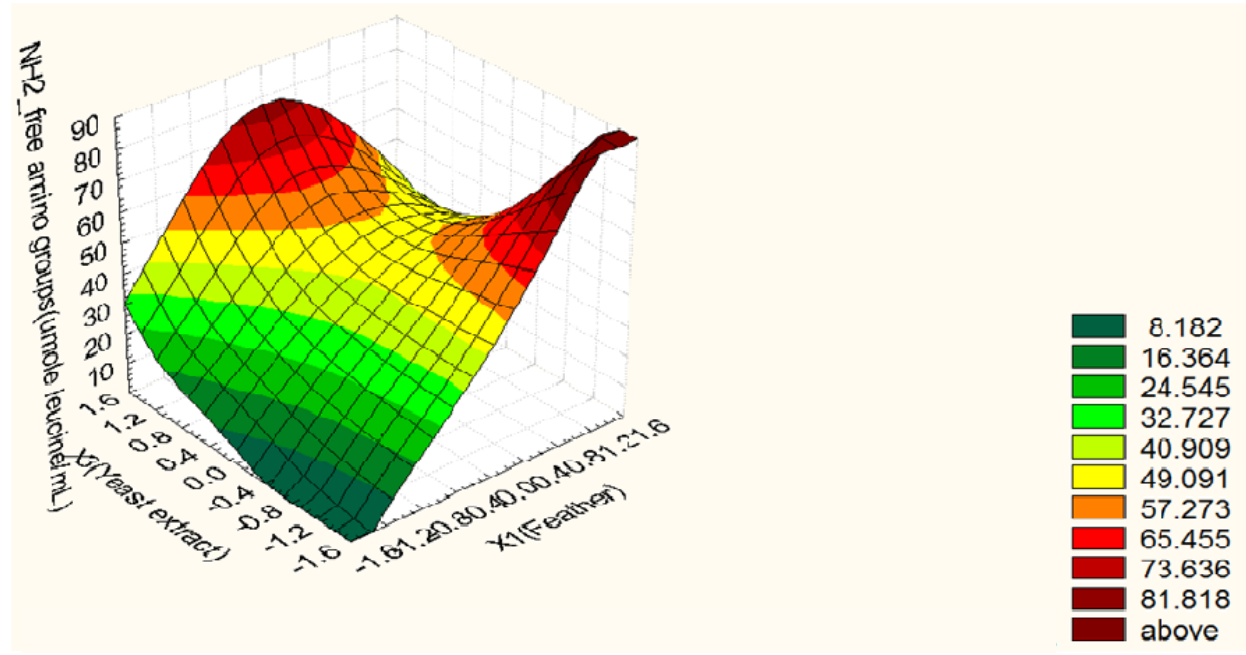

Figure 2b: Three dimensional surface plot for the dependent variable $\mathrm{NH}_{2}$-free amino groups vs. feather and yeast extract.

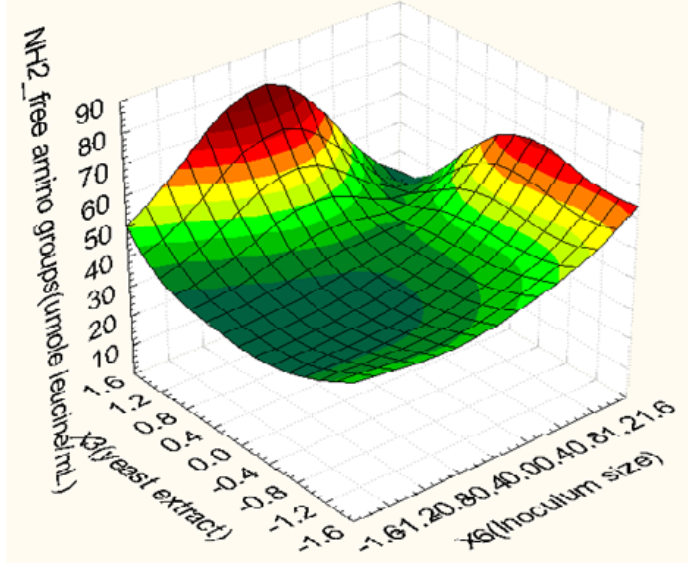




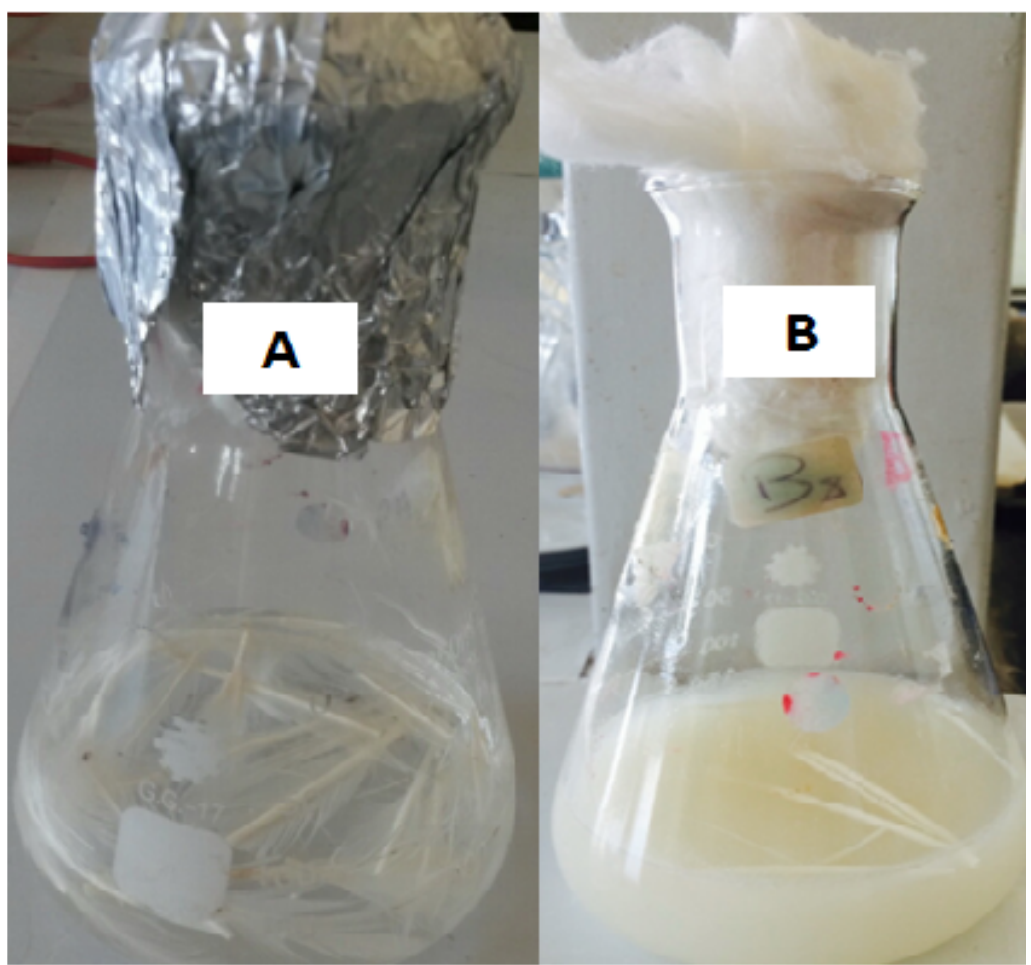

Figure 3: Physical appearance of chicken feather wastes at day zero (A) after 48 hrs (B) Incubation with B. licheniformis SHG 10.

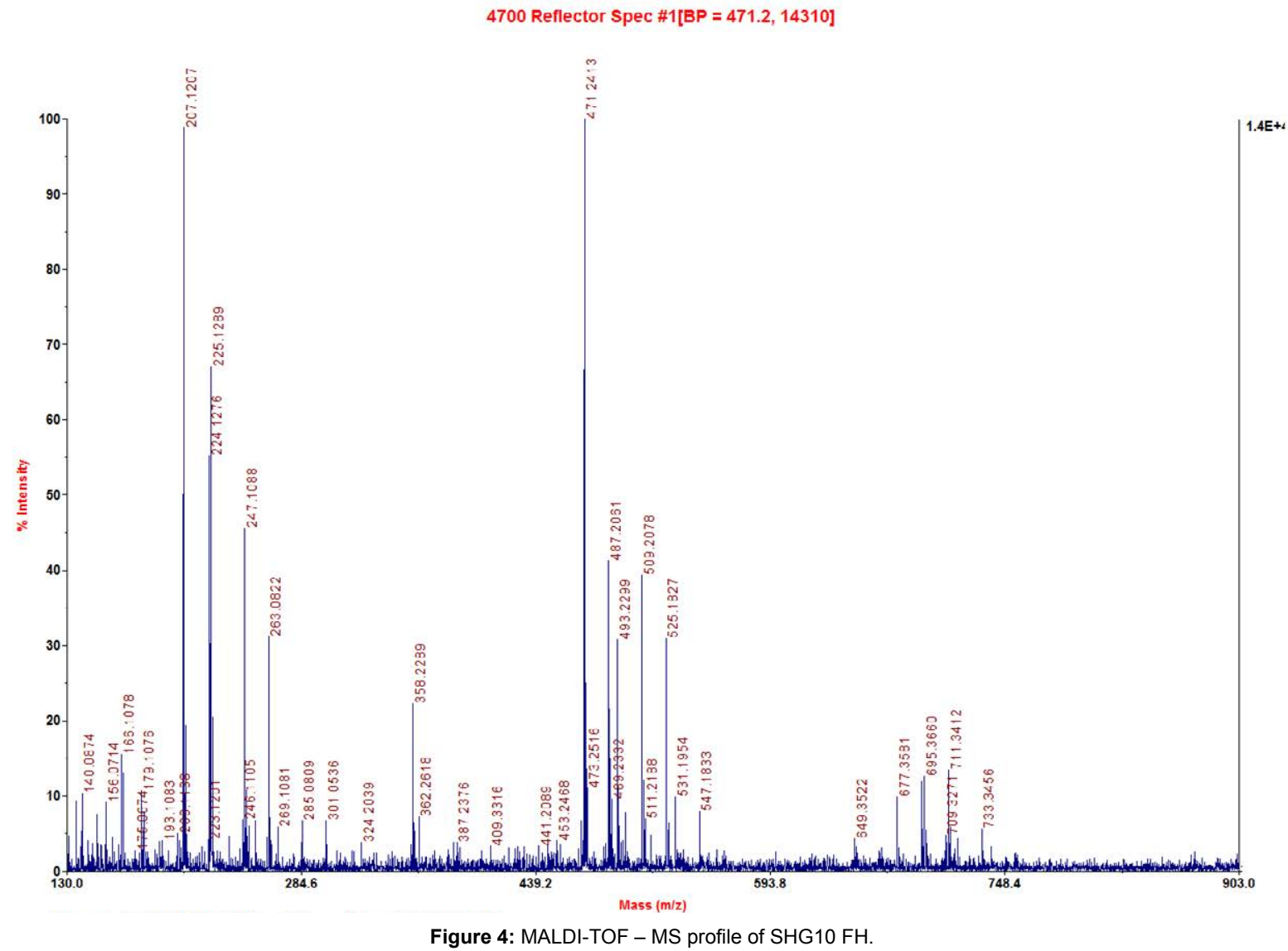




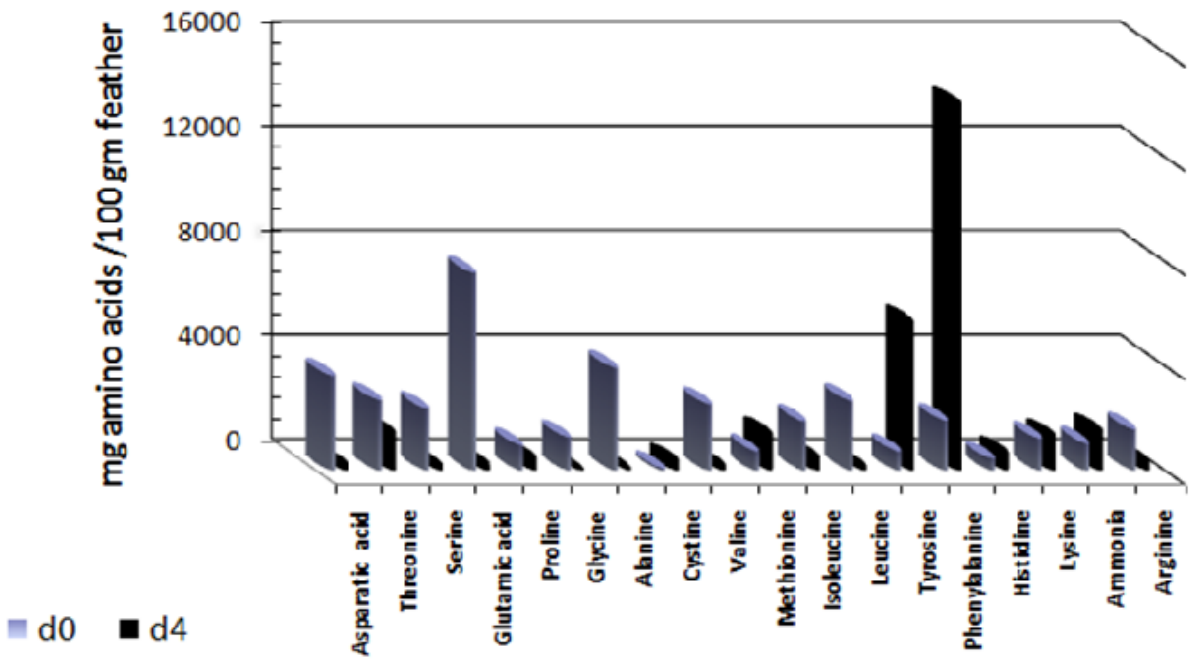

Figure 5: Amino acid profile of SHG10 FH.

amino acids in the resulting feather hydrolysate upon using optimized conditions, modified basal medium II: feather $(\mathrm{X} 1)=1.55 \%(\mathrm{w} / \mathrm{v})$ and yeast extract $(\mathrm{X} 3)=0.03 \%(\mathrm{w} / \mathrm{v})]$ and inoculum size $(\mathrm{X} 6)=9.8 \%(\mathrm{v} / \mathrm{v})$ for production of $\mathrm{NH}_{2}$-free amino groups as mentioned above. Figure 5 displayed the initial levels of amino acids at day zero and those accumulated in feather hydrolysate after four days of incubation. A Fold increase of 7.65, 7.31, 4.14, 1.88 and 1.4 in the levels of tyrosine, phenylalanine, cysteine, methionine and histidine, respectively was noticed at the $4^{\text {th }}$ day of incubation.

\section{Discussion}

Bioconversion of the accumulated non-efficiently utilized chicken feather waste derived from poultry industry worldwide into valuable end products is an issue of a prime importance in the agenda of efficient feathers waste valorization. The up to date literature of review has a main concern for utilizing chicken feather waste in keratinase/ protease production by the aid of feather-degrading microorganisms $[7,16,22,27,28,48,49]$. Therefore, employment of feather waste for soluble proteins and amino acids industrialization is the main interest of the present work.

In the regard of bioprocess industrialization, the transfer from the shake flask scale to the industrial fermenter scale is completely controlled by three issues; a) overall cost of a bioprocess, b) outcome yield and c) time factor. Establishing of a well-designed plan prior carrying out any bioprocess would result in achieving a successful profitable bioprocess fulfilling these three cores prerequisites in a balanced manner. As a matter of fact, maximizing the yield of a bioprocess outcome along with alleviation the possible cost included in a bioprocess is an issue of a prime importance in the agenda of its commercialization. Here, the bioprocess of soluble proteins and amino acids production directed by B. licheniformis SHG10 was studied well from the standpoint of cost effectiveness in conjunction with appreciable yields. From the standpoint of commercialization issue, the overall cost of feathers bioconversion directed by B. licheniformis SHG10 is greatly constricted to the production medium. In this context, an integral empirical statistical sequential approach was applied here in an attempt to construct a very low cost effective production medium that could well support the bacterial growth along with achieving appreciable yield of process outcome (soluble proteins and amino acids) within a relative short time. SHG10 FH production medium (modified basal medium II supplemented with feathers), that could efficiently push the feather bioconversion process into soluble proteins and amino acids, contains the same ingredients at the same levels included in basal medium II. Except that the yeast extract level was increased to $0.45 \%(\mathrm{w} / \mathrm{v})$ and feathers were added at the recommended concentration mentioned above as deduced from the optimization strategy. It is obvious that, SHG10 FH production medium (modified basal medium II supplemented with feathers) is considered a very low cost effective one when compared to other production media reported in the literature in this context. It was reported that the production medium, reinforcing feather bioconversion into soluble proteins via B. licheniformis ZJUEL31410, contained glucose $(20 \mathrm{~g} / \mathrm{L})$, corn steep flour $(7.5 \mathrm{~g} / \mathrm{L})$ and $\mathrm{K}_{2} \mathrm{HPO}_{4}(1 \mathrm{~g} / \mathrm{L})$ [16]. Whilst, feather hydrolysate, obtained upon cultivation of B. subtilis BF 11 and B. cereus BF21 on a production medium designed with starch, soya bean meal and feathers had perceivable levels of total free amino acids [17]. However, feather hydrolysate of a mutant strain of $B$. subtilis had considerable levels of amino acids $22 \mathrm{mg} / \mathrm{mL}$ upon cultivation of this bacterium on a production medium designed with feather meal $(55 \mathrm{~g} / \mathrm{L})$ and maize silage $(8 \mathrm{~g} / \mathrm{L})$ [49]. Conversely, the composition of SHG10 $\mathrm{FH}$ production medium is close to a great extent to other feather hydrolysate production media reported in the literature. Perceivable levels of amino acids in B. altitudinis GVC11 feather hydrolysate upon growing of $B$. altitudinis GVC11 on only raw feathers mixed with distilled water [18]. Feather hydrolysate of Bacillus sp. contained $75 \%$ of crude soluble proteins upon cultivation of Bacillus sp. on basal medium II complemented with feathers [50]. Bacillus sp. MPTK6 feather hydrolysate was rich in soluble proteins, peptides and amino acids upon cultivation of Bacillus sp. MPTK6 on basal medium II supplemented with feathers only [51]. Moreover, feather hydrolysates of three strains of Bacillus sp. and B. subtilis AMR, respectively were rich in soluble proteins upon cultivation of these strains separately on basal medium II sequeled with feathers [12,52]. Apparently, there exist discrepancies in medium composition that favors the production of soluble proteins and amino acids in the resultant feather hydrolysates among different feather-degrading bacteria. These disparities could be 
attributed mainly to differences in nutritional requirements imposed by each feather-degrading microorganism as well as the nature of the kertainolytic proteases produced by the producer microorganisms regarding their preferential inducers from carbon and nitrogen sources. It is worth mentioning that the more kertainolytic protease exists in the culture of the feather-degrading bacteria the more feather biodegradability would be obtained in terms of end products (e.g., soluble proteins and amino acids).

For the yield issue, levels of soluble proteins included in SHG10 FH could not be well evaluated in relation to other soluble proteins levels being involved in other reported feather hydrolysates. Discrepancies in the methods employed in soluble proteins estimation among different feather hydrolysates make unjustified comparisons.

Concerning SHG10 FH protein spectrum on MALDI-TOF-MS, this pattern contained soluble proteins in the range from $140 \mathrm{Da} m / \mathrm{z}$ to $733 \mathrm{Da} \mathrm{m} / \mathrm{z}$. Only two reports highlighted the protein spectrum of feather hydrolysates in the literature [20,52]. The present finding is in partially in agreement with those obtained from B. subtilis SLC feather hydrolysate (522-892 Da) [20], B. subtilis AMR feather hydrolysate (800 to $1079 \mathrm{Da}$ ) and commercial feather meal (900 to $1400 \mathrm{Da}$ ) [52]. These slight discrepancies in protein spectrum among different feather hydrolysates are a consequence of the extent of feather degradation occurring by either physicochemical methods or microbial methods. As a matter of fact, different microbial feather hydrolysates have unique numerous patterns of soluble proteins and amino acids depending not only on the efficiency of each keratinolytic enzyme produced by the microorganism but also on the mechanism of keratin hydrolysis. In addition, most feather hydrolysates reported in the literature were prepared by in vivo methods (i.e., by action of the whole microbial cells on feather keratin not by the action of keratinolytic enzymes alone). In presence of the whole microbial cells, keratinolytic enzymes and disulfide reductase might act synergistically in order to solubilize keratin.

On the other hand, controlling the extent of feather degradability relies on the post applications of the resulting feather hydrolysates that would be involved in. In other words, low molecular weight soluble proteins of feather hydrolysates might be suitable for the cosmetic industry as previously reported [52].

With respect to amino acids content of SHG10 FH, there exists inconsistency in the amino acid content of various reported feather hydrolysates [18,50,51,53-56]. For instance, the levels of lysine (1323 $\mathrm{mg} / 100 \mathrm{~g}$ feather), histidine $(659 \mathrm{mg} / 100 \mathrm{~g}$ feather), methionine (1401 $\mathrm{mg} / 100 \mathrm{~g}$ feather), phenylalanine ( $14032 \mathrm{mg} / 100 \mathrm{~g}$ feather) and tyrosine (5673 mg/100 g feather) in SHG10 FH were 6.6, 10.14, 18.4, 30.5, 19.5 times those of stem and acid hydrolyzed feather [53], respectively. Additionally, levels of phenylalanine and tyrosine in SHG10 FH were 2 and 1.5 fold those of feather hydrolysate of B. licheniformis ER-15, respectively [56]. Conversely, levels of methionine and histidine of B. licheniformis ER-15 feather hydrolysate were superior to those of SHG10 feather hydrolysate. Preferential substrate specificity of the keratinolytic enzymes is the reason behind these disparities in amino acids contents of different feather hydrolysates. The high content of aromatic amino acids such as phenylalanine and tyrosine in SHG10 FH might reflect the preferential specificity of SHG10 keratinolytic protease for cutting nearby the aromatic residues in keratin polypeptides chains. It is noteworthy that SHG10 FH contained perceivable levels of the rare amino acids methionine and histidine. In this context, SHG10 FH has a privilege over some other feather hydrolysates particularly stem cooked feather meals reported in the literature to be potentially added as a complement in animal feed live stocks.

Pertaining to time factor, the more rapid is to carry out a bioprocess, the more feasible is to transfer from shake flask to industrial fermenter scale. In addition, the bioprocess overall cost would be alleviated as the long as the time factor reduces. In this respect, the time included in completing $B$. licheniformis SHG10 feather bioconversion is a relatively short ( $48 \mathrm{hrs)} \mathrm{upon} \mathrm{comparison} \mathrm{with} \mathrm{the} \mathrm{time} \mathrm{required} \mathrm{for} \mathrm{preparation}$ of other reported microbial feather hydrolysates. For instance, perceivable levels of free amino acids in PWD-1 feather hydrolysate could be monitored not before the fourth day [2].

The presence of sulfur-containing amino acid cysteine in SHG10 $\mathrm{FH}$ could support sulphito-lysis mechanism. According to this mechanism, keratinolytic microorganisms cleave disulfide bond included in cysteine of keratin polypeptide chains [17,57]. However, the claimed proposed sulphito-lysis mechanism for feather biodegradation via $B$. licheniformis SHG10 needs further evidences and experimental investigations in prospective studies.

\section{Conclusion}

Concisely, the present study highlights a low cost effective and eco-friendly environmentally approach towards recycling of the non-efficiently and highly accumulated chicken feather waste via its bioconversion into beneficial end products (e.g., amino acids and soluble proteins) by the aid of a feather-degrading soil bacterium namely B. licheniformis SHG10. A statistically optimized low cost effective medium pushing feather bioconversion into soluble proteins and amino acids was addressed in the current study. Further enhancement in the efficiency of this feather bioconversion process could be achieved indirectly via improving the kertainolytic protease productivity from this promising bacterium. This could be perceivable through cloning of the gene encoding this enzyme (providing that its complete nucleotide sequence was previously isolated and published) into a suitable efficient expression vector for homologous expression purposes. Appreciable levels of soluble proteins and amino acids existed in SHG10 FH greatly necessitate the indispensable need for testing its nutritional value on chicken broilers and its potential as a hair care product in prospective studies. Moreover, scaling up the process of feather bioconversion through B. licheniformis SHG10 in a laboratory scale fermenter should be tested in the future before the transfer to the industrial scale.

\section{Authors' Contributions}

Amira M Embaby set all experimental designs. She carried out all laboratory experiments. She participated in statistical analysis of data. Moreover, she wrote and revised the whole manuscript. Heba S Marey carried out statistical analysis of RSM experiments, canonical and ridge analyses. Ahmed Hussein carried out MALDI-TOF experiment, analyzed and interpreted its results.

\section{References}

1. Manczinger L, Rozs M, Vagvolgyi CS, Kevei F (2003) Isolation and characterization of a new keratinolytic Bacillus licheniformis strain. World $\mathrm{J}$ Microbiol Biotechnol 19: 35-39.

2. Williams CM, Richter CS, Mackenzie JM, Shih JC (1990) Isolation, identification, and characterization of a feather-degrading bacterium. Appl Environ Microbio 56: $1509-1515$.

3. Gupta R, Ramnani $P$ (2006) Microbial keratinases and their prospective applications: an overview. Appl Microbiol Biotechnol 70: 21-33.

4. Brandelli A (2008) Bacterial keratinases: Useful enzymes for bioprocessing agroindustrial wastes and beyond. Food Bioprocess Technol 1: 105-116. 
Citation: Embaby AM, Marey HS, Hussein A (2015) A Statistical-Mathematical Model to Optimize Chicken Feather Waste Bioconversion via Bacillus licheniformis SHG10: A Low Cost Effective and Ecologically Safe Approach. J Bioprocess Biotech 5: 231 doi:10.4172/2155-9821.1000231

Page 13 of 14

5. Böckle B, Galunsky B, Müller R (1995) Characterization of a keratinolytic serine proteinase from Streptomyces pactum DSM 40530. Appl Environ Microbiol 61: 3705-3710.

6. Park GT, Son HJ (2009) Keratinolytic activity of Bacillus megaterium F7-, a feather-degrading mesophilic bacterium. Microbiol Res 164: 478-485.

7. Bressollier P, Letourneau F, Urdaci M, Verneuil B (1999) Purification and characterization of a keratinolytic serine proteinase from Streptomyces albidoflavus. Appl Environ Microbiol 65: 2570-2576.

8. Gradisar H, Friedrich J, Krizaj I, Jerala R (2005) Similarities and specificities of fungal keratinolytic proteases: comparison of keratinases of Paecilomyces marquandii and Doratomyces microsporus to some known proteases. Appl Environ Microbiol 71: 3420-3426.

9. Ignatova Z, Gousterova A, Spassov G, Nedkov P (1999) Isolation and partia characterisation of extracellular keratinase from a wool degrading thermophilic actinomycete strain Thermoactinomyces candidus. Can J Microbiol 45: 217-222.

10. Vasileva-Tonkova E, Gousterova A, Neshev G (2009) Ecologically safe method for improved feather wastes biodegradation. Int Biodeter Biodegrad 63: 1008-1012.

11. Onifade AA, Al-Sane NA, Al-Mussalam AA, Al-Zarban S (1998) A review: Potentials for biotechnological applications of keratin-degrading microorganisms and their enzymes for nutritional improvement of feathers and other keratins as livestock feed resources. Biores Technol 66: 1-11.

12. Mazotto AM, Coelho RR, Cedrola SM, de Lima MF, Couri S, et al. (2011) Keratinase Production by Three Bacillus spp. Using Feather Meal and Whole Feather as Substrate in a Submerged Fermentation. Enzyme Res 2011: 523780

13. Williams CM, Lee CG, Garlich JD, Shih JCH (1991) Evaluation of a bacteria feather fermentation product, feather-lysate, as a feed protein. Poul Sci 70 : 85-94

14. Papadopolous MC, El-Boushy AR, Roodbeen AE, Ketelaars EH (1986) Effects of processing time and moisture content on amino acids composition and nitrogen characteristics of feather meal. Animal Feed Sci Technol 14: 279-290.

15. Wang X, Parsons CM (1997) Effect of processing systems on protein quality of feather meals and hog hair meals. Poult Sci 76: 491-496.

16. Ni H, Chen QH, Chen F, Fu ML, Dong YC, et al. (2011) Improved keratinase production for feather degradation by Bacillus licheniformis ZJUEL31410 in submerged cultivation. Afr J Biotechnol 10: 7236-7244.

17. Lakshmi PJ, Chitturi ChM, Lakshmi VV (2013) Efficient Degradation of Feather by Keratinase Producing Bacillus sp. Int J Microbiol 2013: 608321.

18. Kumar EV, Srijana M, Chaitanya K, Reddy YHK, Reddy G (2011) Biodegradation of poultry feathers by a novel bacterial isolate Bacillus altitudinis GVC11. Indian Jiotechnol 10: 502-507.

19. Bihari Z, Vidéki D, Mihalik E, Szvetnik A, Szabó Z, et al. (2010) Degradation of native feathers by a novel keratinase-producing, thermophilic isolate, Brevibacillus thermoruber T1E. Z Naturforsch C 65: 134-140.

20. Cedrola SM, de Melo AC, Mazotto AM, Lins U, Zingali RB, et al. (2012) Keratinases and sulfide from Bacillus subtilis SLC to recycle feather waste. World J Microbiol Biotechnol 28: 1259-1269.

21. Nagal S, Jain PC (2010) Production of feather hydrolysate by Elizabethkingia meningoseptica KB042 (MTCC 8360) in submerged fermentation. Indian J Microbiol 50: 41-45.

22. Anbu P, Gopinath SC, Hilda A, Lakshmipriya T, Annadurai G (2007) Optimization of extracellular keratinase production by poultry farm isolate Scopulariopsis brevicaulis. Bioresour Technol 98: 1298-1303.

23. Gradisar H, Kern S, Friedrich J (2000) Keratinase of Doratomyces microsporus. Appl Microbiol Biotechnol 53: 196-200.

24. Wang L, Cheng G, Ren Y, Dai Z, Zhao ZS, et al. (2015) Degradation of intact chicken feathers by Thermoactinomyces sp. CDF and characterization of its keratinolytic protease. Appl Microbiol Biotechnol 99: 3949-3959.

25. Laba W, Rodziewicz A (2014) Biodegradation of hard keratins by two bacillus strains. Jundishapur J Microbiol 7: e8896.

26. Jitendra K, Kushwaha RKS (2014) Screening of fungi efficient in feather degradation and keratinase production. Arch Appl Sci Res 6: 73-78.
27. Poopathi S, Thirugnanasambantham K Mani C, Lakshmi PV, Ragul K (2014) Purification and characterization of keratinase from feather degrading bacterium useful for mosquito control--a new report. Trop Biomed 31: 97-109.

28. Habbeche A, Saoudi B, Jaouadi B, Haberra S, Kerouaz B, et al. (2014) Purification and biochemical characterization of a detergent-stable keratinase from a newly thermophilic actinomycete Actinomadura keratinilytica strain Cpt29 isolated from poultry compost. J Biosci Bioeng 117: 413-421.

29. Fakhfakh-Zouari N, Haddar A, Hmidet N, Frikha F, Nasri M (2010) Application of statistical experimental design for optimization of keratinases production by Bacillus pumilus A1 grown on chicken feather and some biochemical properties. Process Biochem 45: 617-626.

30. Sivakumar T, Shankar T, Vijayabaskar P, Ramasubramanian V (2011) Statistical optimization of keratinase by Bacillus cereus. Global J Biotechnol Biochem 6: 197-202.

31. Ramnani P, Gupta R (2004) Optimization of medium composition for keratinase production on feather by Bacillus licheniformis RG1 using statistical methods involving response surface methodology. Biotechnol Appl Biochem 40: 191-196.

32. Gupta S, Singh R (2013) Statistical modeling and optimization of keratinase production from newly isolated Bacillus subtilis Rse 163. Inter J Adv Biotechnol Res 4: 167-174.

33. Harde SM, Bajaj IB, Singhal RS (2011) Optimization of Fermentative Production of Keratinase from Bacillus subtilis NCIM 2724. Agric Food Ana Bacteriol 1: 54-65.

34. Kumar J, Kushwaha RKS (2012) Optimization of media composition fo keratinase production on feather by Acremonium strictum RKS1. Adv Appl Sci Res 3: 3233-3242.

35. Cai C, Zheng $X$ (2009) Medium optimization for keratinase production in hair substrate by a new Bacillus subtilis KD-N2 using response surface methodology. J Ind Microbiol Biotechnol 36: 875-883.

36. Bernhard K, Schrempf H, Goebel W (1978) Bacteriocin and antibiotic resistance plasmids in Bacillus cereus and Bacillus subtilis. J Bacteriol 133: 897-903.

37. Bradford MM (1976) A rapid and sensitive method for the quantitation of microgram quantities of protein utilizing the principle of protein-dye binding Anal Biochem 72: 248-254.

38. Pearce KN, Karahalios D, Friedman M (1988) Ninhydrin assay for proteolysis in ripening cheese. J Food Sci 53: 432-435.

39. Moore S, Spackman DH, Stein WH (1958) Automatic recording apparatus for use in the chromatography of amino acids. Fed Proc 17: 1107-1115.

40. Olson MT, Epstein JA, Yergey AL (2006) De novo peptide sequencing using exhaustive enumeration of peptide composition. J Am Soc Mass Spectrom 17: 1041-1049.

41. Plackett RL, Burman JP (1946) The design of optimum multifactoria experiments. Biometrica 37: 305-325

42. Myers RH (1971) Response Surface Methodology. Allyn and Bacon, Boston, USA

43. Dean CB, Nielsen JD (2007) Generalized linear mixed models: a review and some extensions. Lifetime Data Anal 13: 497-512.

44. Douglas CM (2001) Design and analysis experiments. (5thedn) Wiley, Arizona, USA.

45. Myers RH (1976) Response surface methodology. Edwards Brothers, Ann Arbor, MI, USA.

46. Hoerl AE (1959) Optimum solution of many variables equations. Chem Eng Prog 55: 67-78.

47. Draper NR (1963) Ridge analysis' of response surfaces. Technometrics 5 : 469-479.

48. Mousavi S, Salouti M, Shapoury R, Heidari Z (2013) Optimization of Keratinase Production for Feather Degradation by Bacillus subtilis. Jund J Microbiol 6 : e7160.

49. Zhang X (2012) Applying the mutation of Bacillus subtilis and the optimization of feather fermentation medium to improve Keratinase activity. Adv Biolog Chem 2: 64-69.

50. Deivasigamani B, Alagappan KM (2008) Industrial application of keratinase and soluble proteins from feather keratins. J Environ Biol 29: 933-936. 
Citation: Embaby AM, Marey HS, Hussein A (2015) A Statistical-Mathematical Model to Optimize Chicken Feather Waste Bioconversion via Bacillus licheniformis SHG10: A Low Cost Effective and Ecologically Safe Approach. J Bioprocess Biotech 5: 231 doi:10.4172/2155-9821.1000231

Page 14 of 14

51. Kumar DJM, Priya P, Balasundari SN, Devi GSDN (2012) Production and Optimization of Feather Protein Hydrolysate from Bacillus Sp. MPTK6 and its Antioxidant Potential. Middle-East J Sci Res 11: 900-907.

52. Villa AL, Aragão MR, Santos EP, Mazotto AM, Zingali RB, et al. (2013) Feathe keratin hydrolysates obtained from microbial keratinases: effect on hair fiber. BMC Biotechnol 13: 15

53. Eggum BO (1970) Evaluation of protein quality of feather meal under differen treatments. Acta Agric Scand 20: 230-234.

54. Fellahi S, Zaghloul TI, Feuk-Lagerstedt E, Taherzadeh MJ (2014) A Bacillus Strain Able to Hydrolyze Alpha - and Beta- Keratin. J Bioprocess Biotech 4: 181.
55. Zaghloul TI, Embaby AM, El-Mahdy AR (2011) Biodegradation of chicken feathers waste directed by Bacillus subtilis recombinant cells: scaling up in a laboratory scale fermentor. Bioresour Technol 102: 2387-2393.

56. Tiwary E, Gupta R (2012) Rapid Conversion of Chicken Feather to Feather Meal using Dimeric Keratinase from Bacillus licheniformis ER-15. J Bioprocess Biotech 2: 123.

57. Gupta S, Singh R (2014) Hydrolyzing proficiency of keratinases in feather degradation. Indian J Microbiol 54: 466-470. 